\title{
The Separation of Powers and the Protection of Children
}

\author{
Ira C. Lupu†
}

This Special Issue focuses upon the interplay among individuals, associations to which those individuals (or others acting for them) have entrusted their concerns, and the state. In our society, such associations serve crucial functions. By creating for their constituent members a sense of common purpose and a source of connection to others, these associations help establish a coherent nexus to what may seem an incomprehensible and careening world. ${ }^{1}$ At times, such institutions may exert social, economic, political, or moral power, but have no real capacity to alter the legal status of their constituent members. In some circumstances, however, the relationship of an individual to the state becomes transformed by virtue of the individual's relationship to an association with its own distinctive legal character. In such cases, the association may act as a buffer, or mediator, between the impersonal state and the otherwise isolated individual. Voluntary entry into such associations represents a choice, within often-contested boundaries, to submit to associational rules and jurisdiction in exchange for whatever benefits-psychic, material, or otherwise-membership may confer.

In this Issue's other contributions, the state, associations, and concerned individuals all have full legal capacity, and most

† Louis Harkey Mayo Research Professor of Law, The National Law Center, The George Washington University. Thanks to Dean Friedenthal and others at the National Law Center for institutional support; to Nancy Altman, Naomi Cahn, Jane Cohen, Miriam Galston, Philip Hamburger, Bill Marshall, Joan Meier, Fran Miller, Larry Mitchell, Ted Sims, and Bob Tuttle for helpful comments on this piece in manuscript; to Nancy Gordillo for excellent research assistance; and to my wonderful children, one born in each of four separate decades (Toni Lupu-Sax, 1968; Adam Lupu-Sax, 1971; Jennifer Altman-Lupu, 1987; Michael Altman-Lupu, 1990). My experience with the four of them, more than anything else, has taught me the importance of having influences separate from-indeed, sometimes opposed to-my own in their lives. To the extent it may be relevant, the reader should know that I had joint legal custody of Toni and Adam after their mother and I divorced in 1982.

1 As Professor Dan-Cohen's article in this Special Issue so well demonstrates, collective entities take many different forms and perform many different social and psychological functions. See generally Meir Dan-Cohen, Between Selves and Collectivities: Toward a Jurisprudence of Identity, 61 U Chi L Rev 1213 (1994). 
of the important questions involve attempts by one actor to disturb consensual arrangements between the other two. When the state comes between individuals and associations, it trumps private contract, individual freedom, and associational freedom. ${ }^{2}$ When an individual invokes state-supported norms and legal machinery in an attempt to disrupt arrangements among an association's constituent members, one set of citizen interests may be pitted against another. ${ }^{3}$

In disputes involving the interests of children, however, the legal dynamics change considerably. Because children ordinarily lack legal capacity to decide major matters for themselves, disputes that would be triangular in form among adults are instead legally bilateral. That is, the conflicts primarily involve the state and the mediating entity - the family or other custodian-without the independent, autonomous voice of the child being heard in the formal legal controversies. Even when a family is shattered and the disputants are private custody seekers or other adults with legally protected interests in their relationship with a child, the state remains present through its laws and its decision makers, while the child will, at most, be represented in the proceeding by surrogates with duties of loyalty to the system as well as the child. ${ }^{4}$

Our legal regime purports to respect children but generally disempowers them. Accordingly, we rely on a system of fiduciary arrangements to protect children's interests, assigning power over children to those whom we believe deserve this trust. These fiduciaries may be educators, social workers, medical profession-

${ }^{2}$ See, for example, Bob Jones University $v$ United States, 461 US 574 (1983) (upholding loss of a tax exemption for a religiously oriented university with a racially discriminatory policy governing social interaction among students). Professor Gillette's article in this Special Issue analyzes this phenomenon in the context of residual communities. Clayton P. Gillette, Courts, Covenants, and Communities, 61 U Chi L Rev 1375 (1994).

3 For an example of mediating institutions trying to buffer the relationship between individuals and the state, see McClure $v$ Salvation Army, 460 F2d 553, 560-61 (5th Cir 1972) (construing the federal prohibition of gender discrimination in employment to exclude hiring by religious organizations for clergy positions).

4 Through devices like appointment of guardians ad litem for children, courts are at times able to include in their proceedings a form of representation for children that is not under the direct control of the children's custodians. See Homer H. Clark, Jr., 1 The Law of Domestic Relations in the United States \$ 9.4 at 559-60 (West, 2d ed 1988). Even in such circumstances, however, the courts rarely hear the child's own voice directly. The responsibility of a guardian ad litem is to report facts concerning her ward, rather than to ensure that the ward's preferences are expressed. Moreover, all child advocacy by adults is likely to be colored by the adult's interests and values. See John E. Coons, Robert H. Mnookin, and Stephen D. Sugarman, Puzzling over Children's Rights, 1991 BYU L Rev 307, 333-39. 
als, clergy, or others, although most often they are family members. Thus, in other settings, mediating institutions may add their voices as advocates to those of the individuals whom they represent, and the possibility of legally cognizable individual dissent remains. For children, all the power the legal system allots to resist wrongs and encroachments by others resides in fiduciary hands, usually familial. ${ }^{5}$

The general justification for this arrangement is not hard to fathom. Most children, especially the very young, do not possess an adequate basis for making judgments concerning their longterm well-being. Consequently, the legal system allocates power over them to those who are presumed to have both information and affection-that is, to persons who have day-to-day contact and the family ties thought likely to produce care, concern, and attention. ${ }^{6}$ Surely such a system is far more consonant with the values of a liberal society than a system in which power over the details of children's lives resides in the impersonal state.

Fiduciaries, however, can violate their duties through inattention or carelessness. Worse, self-interested fiduciaries may dominate, exploit, and abuse their wards. The harms to children-and to society as a whole-that follow from such misconduct can be long lasting and widespread. Permitting such harms to the most vulnerable creatures among us does not square with the same values that lead to a parent-centered, rather than a state-centered, system.

This Article argues that structural insights drawn from the concept of separation of government powers may guide solutions to the problems created by granting legal power over children to mediating institutions. Section I briefly identifies some qualities of government power separation that can be articulated-and should be encouraged-in the family setting. Section II argues explicitly that the underlying concerns of power separation fit the experience of families and children. Section III divides issues relating to children into subcategories of intrafamilial power separation and extrafamilial power separation, and then uses the concept of power separation to analyze a number of discrete

- See Katharine T. Bartlett, Rethinking Parenthood as an Exclusive Status: The Need for Legal Alternatives When the Premise of the Nuclear Family Has Failed, 70 Va L Rev $879,883-85$ (1984) (cataloguing the exclusive rights and duties of parents).

6 See, for example, Parham v J.R., 442 US 584, 602 (1979) (" $[\mathrm{H}]$ istorically, [the law] has recognized that natural bonds of affection lead parents to act in the best interests of their children."), citing William M. Blackstone, 1 Commentaries $* 447$, and James Kent, 2 Commentaries on American Law $* 190$. 
issues-among them joint legal custody, adoption by single parents and same-sex couples, disputes over the religious training of children of divorced parents, home education, and abortion and other medical treatment for minors.

A set of substantive premises underlies the structural analysis that occupies this Article. These premises include: (1) society has a general and strong interest in the well-being and development of children; (2) legal arrangements concerning children should make paramount their interests, not the interests of the adults who care for and fight over them; (3) adults are all fallible, imperfect, and self-regarding in their interaction with children; (4) children cannot be completely sheltered from conflict; (5) children are best reared in regimes of adult equality, in which patriarchy and matriarchy are equally discouraged; and (6) some matters, most notably those concerning health and education, are too important to the well-being of children and society to be entrusted exclusively to any single entity, the family included.

The view of family life offered here will resonate with some but be counterintuitive to others. If the reader finds herself parting company with what the Article advocates, it may be because she does not share the above premises (on grounds of fact or value), or has a different view of human nature. Alternatively, the reader may not be comfortable with the suggestion that she relinquish power with respect to some issues over which, or persons over whom, she would prefer to exercise more control rather than less. Power separation, after all, is never designed to be in the interests of the power holder; it is designed to check those interests.

\section{Power Separation AND the Preservation of Liberty}

Democratic governments must confront the problem of controlling the state. As Federalist 51 puts it:

In framing a government which is to be administered by men over men, the great difficulty lies in this: you must first enable the government to control the governed; and in the next place oblige it to control itself. ${ }^{7}$

Once the people have surrendered some of their liberty to the state, how can they ensure that tyranny will not follow? In the

7 Federalist 51 (Madison), in Clinton Rossiter, ed, The Federalist Papers 320, 322 (Mentor, 1961). 
United States, a central component of the response to that question has been the separation of powers within the government. The theory and practice of modern democracy depends considerably on such power separation and the resulting system of checks and balances among the branches of government. ${ }^{8}$

The need for power separation and interbranch checks and balances arises from a specific theory of human nature. Federalist 51 made this explicit: "If men were angels, no government would be necessary." ${ }^{\prime \prime}$ Of course, human experience and insight show that no one-least of all one who seeks power-is wholly virtuous. Though we may define our interests differently, some in material terms and others by intangible values, humans are all corruptible. ${ }^{10}$ Each person seeks to accumulate whatever goods she values. Each has a social vision, implicit or otherwise, that supports his sense of well-being and desire. Each sees the world through distorting lenses of personal experience and psychic need.

That some people have power over the affairs of others renders our nonangelic characters more threatening. Although the natural human capacity for empathy, coupled with social and cultural expectations associated with power over others, may lead people in dominant positions to act in the best interests of their wards, less salutary dynamics may develop. For those who have a will to power, its acquisition may easily lead to self-justifying rationalizations. Power holders may tell themselves that their urges to dominate others or replicate the world in their own image are aspirations to the common good rather than acts of corrupt or egoistic self-interest.

To guard against the threat to individual liberties associated with the imperfection and corruptibility of individuals who hold

B For a comprehensive account of the evolution of ideas relating to the separation of powers in government, see M.J.C. Vile, Constitutionalism and the Separation of Powers (Clarendon, 1967).

9 The Federalist Papers at 322 (cited in note 7).

${ }^{10}$ Some feminist jurisprudence might be read to support the view that women are relatively more virtuous than men. See, for example, Robin West, Jurisprudence and Gender, 55 U Chi L Rev 1, 13-28 (1988) (arguing that feminist jurisprudence emphasizes connections to other human beings, while masculine jurisprudence emphasizes separations); Martha Minow, "Forming Underneath Everything That Grows": Toward a History of Family Law, 1985 Wis L Rev 819, 884-94 (describing how women brought family values of nurturing and connectedness into the larger world of governance). See generally Carol Gilligan, In a Different Voice (Harvard, 1982); Suzanna Sherry, Civic Virtue and the Feminine Voice in Constitutional Adjudication, $72 \mathrm{Va} L \mathrm{Rev} 543$ (1986). Even these feminist thinkers do not assert that a polity governed by women would be one in which power separation was unnecessary. 
government power, American democracy relies on a system of divided government in which different branches and agencies of government monitor and limit one another. This separation of powers safeguards individual rights in at least two related, but conceptually distinct, ways. First, it provides a structural protection against tyranny by generating a bias toward inaction. Most important acts of government require concurrence by two or more branches of government. ${ }^{11}$ It will always be more difficult to get two or more entities of government to act than to get one branch to do so. By thus driving up the costs of securing political action, concurrence requirements reduce the likelihood of domination of the society by a small and self-interested faction.

Separation of powers also protects individual liberties through institutional specialization. By placing the powers of lawmaking, law enforcement, and law interpretation in different hands, democracies limit the extent to which the self-interest of their officials can produce a corrupt outcome. ${ }^{12}$ For the society as a whole to restrict or coerce its citizens through its governing agencies, each branch must perform its constitutionally assigned task. But because our legislatures, executives, and judiciaries have their own political support, institutional design, and modes of decision making, each will frequently have its own angle of vision on a particular problem or phenomenon. These interbranch differences in perspective, coupled with the interbranch coopera-

1 Legislative bicameralism, as it exists at the federal level and in many states as well, adds an additional concurrence requirement-two separately constituted legislative assemblies must concur before the legislative branch as a whole has concurred. Delegation of legislative power to executive branch agencies threatens the protection afforded by requirements of near-contemporaneous concurrence. As a result, we have developed alternative mechanisms to protect the values associated with concurrence requirements in the original scheme. For a discussion, see Abner S. Greene, Checks and Balances in an Era of Presidential Lawmaking, $61 \mathrm{U}$ Chi L Rev 123 (1994). As I discuss in the beginning of Section III, the analogy between government and family is imperfect. Too much bias toward inaction in the case of parents and children would be destructive of children's wellbeing. Accordingly, family law includes substantive prohibition, without equivalent in the government-adult relation, against neglect of children by their custodians. See text accompanying notes 119-25.

12 In the American model of power separation, for example, legislators must pass general laws, without guarantees that they or their allies will be exempt from the laws' coverage; executives have enforcement discretion but cannot dictate the content of the laws to be applied; and the judiciary must adjudicate disputes impartially under law it does not create, in actions that others have decided to bring. There are, of course, numerous departures from the pure model of separation of powers, but they continuously produce a demand for justification in ways that adherence to the basic allocation of power in the model does not. For a discussion of the uniquely American contribution to separation of powers, see Vile, Constitutionalism at 119-75 (cited in note 8). 
tion required to produce government action, decrease the possibility of oppressive mistreatment of a portion of the citizenry. Described more positively, these features of power separation enhance the likelihood that governmental decisions are carefully considered and respectful of the concerns of those affected. ${ }^{13}$

\section{Power Separation AND the Interests of ChILDREN}

What does constitutional theory concerning the relationship between liberty and the allocation of power in government have to do with the interests of children? ${ }^{14}$ On the surface, the answer is nothing. After all, children are ordinarily entrusted to adults, not to government agencies. Indeed, when government takes charge of children, we view the situation as short term and in need of a private solution-for example, placement for adoption or foster care. Moreover, when power over children is separated among adults, the structure within which it is exercised appears nothing like what we observe when we look at government, with its massive institutions, bureaucratic staff structure, and public responsibility. ${ }^{15}$ Rather, power over any particular child ordinarily belongs to only a few adults.

Yet the model of separated powers, carefully designed specialization of function, and balanced institutional relations has much to teach those who concern themselves with the interests of children. For although the Framers themselves likely subscribed to the late-eighteenth-century view that family members shared a natural loyalty and affection, and thus that families were dramatically different from civil society at large ${ }^{16}$ twentieth-cen-

13 Of course, these structural protections are not always sufficient to prevent the government from acting wrongfully. Rights guarantees, and their judicial enforcement, are therefore also necessary to prevent wrongful action by the government. Rights and structure, however, are frequently intertwined. For a discussion of the structural foundations of the federal Bill of Rights, see Akhil Reed Amar, The Bill of Rights as a Constitution, 100 Yale L J 1131 (1991).

14 I focus in this Article on the interests of children, and not other vulnerable persons who lack full legal capacity. The arguments I advance here about power separation could be made with equal force with respect to all classes of persons without such capacity. The mentally incompetent, and in particular the elderly among the mentally incompetent, might benefit from application of this analysis.

15 For a tentative suggestion that the legal underpinnings of government may resemble those of families, rather than the other way around, see Minow, 1985 Wis L Rev at 819 (cited in note 10) (Family law's rules about roles and duties underlie other legal fields, including "perhaps the governance of the state.").

${ }_{16}$ See Adam Smith, The Theory of Moral Sentiments, 219-20 (Clarendon, 1976) (D.D. Raphael and A.L. Macfie, eds) (arguing that the exclusivity of families provides its members with a sense of common destiny and mutual commitment). The Framers were well 
tury insights into family dynamics have cast doubt upon the force of this distinction. Whether or not these dynamics have in fact changed over the past two hundred years, it is now clear that the psychological forces at play in family life are not limited to the positive sentiments of affection and concern. Far more destructive elements, often involving struggles for love, affection, authority, and status, are also present. ${ }^{17}$ Thus, while the risks to

acquainted with Adam Smith, whose Wealth of Nations was first published in 1776, and whose The Theory of Moral Sentiments was first published in 1759. As recounted in Professor Federle's recent study, John Locke--whose views on government influenced the Framers-had a view of family and children quite different from most of his philosophical contemporaries. In particular, Locke was an opponent of absolute patriarchy-both in the kingdom and in the family - and a defender of the rights of mothers and children against patriarchal power. See Katherine Hunt Federle, On the Road to Reconceiving Rights for Children: A Postfeminist Analysis of the Capacity Principle, 42 DePaul L Rev 983, 991-93 (1993). Locke did, however, draw on the analogy between the government of children within a family and the government of civil society in Chapter VI ("Of Paternal Power") of The Second Treatise of Government (Liberal Arts, 1952). Locke's treatises were in part a response to Sir Robert Filmer's Patriarcha, which had argued for the absolute power of kings over their subjects and fathers over their children.

Thomas Jefferson's letters to his own family members suggest that he held to an idealized version of family. In one letter, Jefferson wrote:

I now see our fireside formed into a groupe no one member of which has a fibre in their composition which can ever produce any jarring or jealousies among us. No irregular passions, no dangerous bias, which may render problematical the future fortunes and happiness of our descendants. We are quieted as to their condition for at least one generation more.

Edwin M. Bells and James A. Bear, Jr., eds, The Family Letters of Thomas Jefferson 146 (Missouri, 1966) (letter to Martha Jefferson Randolph, June 8, 1797). In the same letter, Jefferson contrasted family life with his political life, to which he had recently returned after becoming Vice-President:

When I look to the ineffable pleasures of my family society, I become more and more disgusted with the jealousies, the hatred, and the rancorous and malignant passions of this scene, and lament my having ever again been drawn into public view.

Id. In a letter to another daughter, Jefferson stated:

The circle of our nearest connections is the only one in which a faithful and lasting affection can be found, one which will adhere to us under all changes and chances. It is therefore the only soil on which it is worthwhile to bestow much culture. Of this truth you will become more convinced every day you advance into life.

Id at 170 (letter to Mary Jefferson Eppes, Jan 1, 1799).

Historians have suggested that Jefferson's true feelings about his family were somewhat more complex. See Kenneth A. Lockridge, On the Sources of Patriarchal Rage: The Commonplace Books of William Byrd \& Thomas Jefferson and the Gendering of Power in the 18th Century 69-71 (NYU, 1992) (arguing that Jefferson's letters and his "commonplace book"-in which he transcribed excerpts of the writings of others that interested him-suggest an unloving relationship with his mother, a fear of female sexuality linked with a passion for cleanliness as expressed to his daughter, and a general misogyny).

17 See, for example, Sigmund Freud, A General Introduction to Psychoanalysis 329-47 (Washington Square, 17th ed 1967) (Joan Riviere, trans) (describing the Oedipus complex 
which children are exposed from the behavior of adults with power over them are not necessarily of the same species as those associated with tyrannical government, they may well be of the same genus. To safeguard children's well-being, it may therefore be necessary to divide power over children, much as the Framers divided government power over individuals.

Indeed, the Framers knew well the problem of self-love and its tendency to corrupt government decision makers. ${ }^{18}$ But if self-love is a danger in government, what are we to make of its role in child rearing? ${ }^{19}$ Do we not expect self-love-as it is expressed from parent to child - to be multifaceted and filled with tension? Of course, many parents have deep and abiding concern, affection, and respect for the children under their guidance. These sentiments may compel them to check their self-love; for example, a parent may realize that the child's best interests might not coincide with what will make the parent feel most proud, comfortable, or flattered. Such parents will restrain the urge to act in their own interest, rather than the child's.

and other libidinous constructs developed within the family); Anthony Storr, Freud 20-29 (Oxford, 1989) (commenting on current understandings of Freud's theories of infantile sexual development); C.G. Jung, The Family Constellation, in Sir Herbert Read, et al, eds, 2 The Collected Works of C.G. Jung 466, $466-79$ (Princeton, 1973) (Leopold Stein, trans) (discussing how family tensions and conflict can cause neuroses); Erik H. Erikson, Childhood and Society 326-358 (Norton, 2d ed 1963) (describing conflicts in Hitler's childhood and adolescence that shaped his personality); R.D. Laing, The Politics of the Family and Other Essays (Pantheon, 1971). Feminist psychology has reworked the field, but has not eliminated the focus on conflict. See Jean Baker Miller, Toward a New Psychology of Women (Beacon, 1976) (describing and analyzing intrafamilial conflict clustered around issues of gender domination and subordination); Dorothy Dinnerstein, The Mermaid and the Minotaur: Sexual Arrangements and Human Malaise (Harper Colophon, 1976) (discussing the social bases of gender roles); Nancy Chodorow, The Reproduction of Mothering: Psychoanalysis and the Sociology of Gender (California, 1978) (same); Jean F. O'Barr, Deborah Pope, and Mary Wyer, eds, Ties That Bind: Essays on Mothering and Patriarchy (Chicago, 1990) (same). In the most extreme cases, mistreatment of children can lead to violent retaliation within the family. See generally Kathleen M. Heide, Why Kids Kill Parents (Ohio State, 1992).

18 Madison's Federalist 10 contains the classic statement of the problem:

As long as the reason of man continues fallible, and he is at liberty to exercise it, different opinions will be formed. As long as the connection subsists between his reason and his self-love, his opinions and his passions will have a reciprocal influence on each other; and the former will be objects to which the latter will attach themselves.

The Federalist Papers 77, 78 (cited in note 7).

19 In his acclaimed $A$ Treatise on the Family (Harvard, enlarged ed 1991), Nobel laureate (Economics) Gary Becker asserts conclusorily that "altruism is generally recognized to be important within a family." Id at 277. Yet even Becker's quotation from Adam Smith on the point begins by stating that "[a]fter himself, the members of [a man's] own family ... are naturally the objects of his warmest affections." Id (emphasis added). 
But to say this is to say no more than that some parents will be unusually virtuous in the discharge of their trust, resisting temptations to self-deal. Of course, some such parents will exist, just as politics will occasionally attract unusually virtuous participants whose energies are truly focused on the common good. Our institutions, however, should be designed against the possibility that we are weak and fallible rather than in the hope that we are strong and self-denying.

Moreover, self-love may be an unusually corrupting force when it comes into play in a parent-child relationship. When a politician or corporate official advances the interests of himself, his class, or his cronies, one would expect that he would at least be aware of the tension between his own interests and those of the commonwealth; cognitive dissonance has its limits. In the parent-child relationship, however, the capacity for self-deception may be at its maximum. Because the parent is socially and psychologically reinforced to view her relationship with the child as one of affectionate personal attachment, the parent may be unusually blind to the possibility that self-love is distorting her judgment. Moreover, one can much more easily justify domination of children, who obviously need some degree of care and guidance, than one can justify comparable (mis)treatment of adults. ${ }^{20}$

The problem of parental self-interest may be further aggravated by the deep sense of identification many parents have with their children. This sense may be inspired by a parent's perception of his own mortality. Children represent a medium through which adults may maintain the psychically comforting illusion that they can live on after their bodies have expired. It is hardly

${ }^{20}$ The longstanding power of literary accounts of parents who act destructively toward their children is powerful testimony to the capacity of self-love, among other potentially corrupting forces, to contribute to tragically bad behavior toward those whom we profess to care for the most. A biblical example is Abraham's willingness to sacrifice his son Isaac in order to preserve Abraham's relationship with God. Genesis 22: 1-18. The story of Christianity resonates with the Abraham-Isaac story; Christianity's original passion arises from God's willingness to let His Son suffer and die in body. Other examples include King Leontes's jealousy toward his wife leading him to abandon his daughter and fatally neglect his son, in William Shakespeare's $A$ Winter's Tale (Penguin, $2 \mathrm{~d}$ ed 1968); a father and husband abusing his family in response to abuse he experiences at work, in James Joyce's Counterparts, in Dubliners 86 (Penguin, 1976); a patriarch's racial prejudice leading him to foment destructive conflicts among his children in William Faulkner's Absalom, Absalom! (Random House, 1986); and a mother murdering her infant daughter out of fear that the daughter will be enslaved, in Toni Morrison's Beloved: $A$ Novel (Knopf, 1987). 
surprising that mortals should want to maximize their control of this legacy. ${ }^{21}$

What should be the social response to the dangers of custodial domination of children? As Professor Woodhouse has carefully documented, Americans buried these concerns for a good part of our history under an ideology that assimilated children to property. ${ }^{22}$ If social expectations concerning the treatment of children lie on a moral level with those associated with farm animals or human chattel, ${ }^{23}$ one cannot be surprised that the oppression of children does not produce an articulated and visible social response.

Now that we have begun to realize a more child-centered view of the family and our social future, however, we are left with a set of uneasy choices. We obviously cannot expect children themselves to be the best monitors of the adults who care for them. Whether by nature or nurture, children are often intensely loyal to and intensely afraid of losing (or displeasing) their custodians. As a result, children are not likely to report maltreatment or-particularly in the case of younger children-even to recognize it when it occurs. And even when children are consciously unhappy over the ways in which they are being treated, they are ill-equipped to resist or retaliate in a manner sufficient to alter their parents' childrearing. Because so much bad or insensitive treatment goes on in private-where only family members can witness it-quite frequently it is only other adult family members who can check it.

Our need for family members, or someone in close proximity to them, to check one another's treatment of children is not limited to the crucial yet minimalist agenda of protecting children from physical violence or brutal conditions of deprivation. Because society's future is always in its children's keeping, we must focus as well on affirmative conditions of well-being. In various ways, our society expresses its visions of what its children should

${ }^{21}$ I thus believe there is vast overstatement in Bruce Hafen's claim that "the sense of family duty has an uncanny power to produce [altruism] in ways that defy Adam Smith's assumption that self-interest is man's dominant value." Bruce C. Hafen, The Constitutional Status of Marriage, Kinship and Sexual Privacy-Balancing the Individual and Social Interests, 81 Mich L Rev 463, 476 (1983).

${ }_{22}$ Barbara Bennett Woodhouse, "Who Owns the Child?": Meyer and Pierce and The Child as Property, 33 Wm \& Mary L Rev 995 (1992).

${ }^{23}$ Id at 1036-50. Professor Seipp suggests that early common law was not openly receptive to the idea that children were equivalent to property, though the law did not entirely reject that one could have property in another. See David J. Seipp, The Concept of Property in Early Common Law, 12 L \& Hist Rev 29, 85-86 (1994). 
be: well-housed, well-fed, healthy, physically fit, well-educated, well-rounded, competitive, caring, and culturally enriched. ${ }^{24}$ If we are serious about these values, we need a structure of custodianship designed to promote them.

Multiplying and separating power over children advances both our affirmative social agenda of equipping children to face the future and our negative goal of minimizing harm to them. Because children are so vulnerable, and so limited in their ability to combat threats to their well-being from the adults central to their lives, we frequently depend on one or more of those adults to check and limit the others. ${ }^{25}$ Because no individual adult has perfect vision and the capability to execute a plan for the complete nourishment of a child's positive development, we must often depend on the mix of adults in a child's life to create the conditions for that development. ${ }^{26}$

Of course, the concern expressed here is often addressed in customary social arrangements. For years, the social norm in America for families with children was two-parent (opposite gender) families, in-wedlock births, and significant involvement in the socialization and development of children by persons outside the family-neighbors, teachers, doctors, and religious leaders, among others. ${ }^{27}$ More recently, however, a number of social and

24 See, for example, Carnegie Task Force on Meeting the Needs of Young Children, Starting Points: Meeting the Needs of Our Youngest Children 105-12 (Carnegie Corp of NY, 1994); A National Agenda for Children: On the Front Lines with Attorney General Janet Reno, Juvenile Justice 2 (Fall/Winter 1993); Beyond Rhetoric: A New American Agenda for Children and Families (National Commission on Children, 1991).

${ }^{25}$ See Eleanor E. Maccoby and Robert H. Mnookin, Dividing the Child: Social and Legal Dilemmas of Custody 31 (Harvard, 1992) (discussing the concept of parental "buffering," in which one parent protects the child from the other parent). Of course, the check from the other does not always prevail. The horrendous story of Lisa Steinberg, beaten to death by her father, Joel Steinberg, and the inability of her battered, drug-using mother, Hedda Nussbaum, to protect her from the beatings, was a vivid reminder of the limited ability of the family to protect against violence from one of its own. See Ronald Sullivan, Stifling Tears, Nussbaum Recounts Lisa's Last Days, NY Times B1 (Dec 2, 1988); Editorial, The Fascination of the Abomination, NY Times A24 (Feb 1, 1989).

${ }^{26}$ It is true that separation of powers tends to facilitate the blocking of action more than the taking of action. See Vile, Constitutionalism at 14 (cited in note 8) ("[O]ne of the most persuasive general criticisms of the doctrine [of separation of powers] is that it has been associated with an essentially negative view of political liberty, one too concerned with the view of freedom as absence of restraint ...."). This concern, among others, leads me to argue for the advantages of two parents, rather than any larger number, as the optimum number for children. See text accompanying notes 34-41.

${ }^{27}$ See Bartlett, $70 \mathrm{Va} \mathrm{L} \mathrm{Rev} \mathrm{at} 879 \mathrm{n} 1$ (cited in note 5) (reviewing literature describing different family arrangements "throughout history and among different social classes," and concluding that "the private, largely self-contained, marriage-centered nuclear family has been the norm throughout most of American history"). 
legal phenomena have threatened this customary norm. The divorce rate exploded thirty years ago, propelling many children into single-parent households. ${ }^{28}$ At the same time, the percentage of children born to unmarried parents has increased dramatically. ${ }^{29}$ Moreover, an increasing number of children are being home schooled..$^{30}$ If power separation over children is psychologically and socially important, now may be a crucial time to explicitly reassert it. ${ }^{31}$

At the margin of these developments, the law plays a part. It can reinforce these trends, express neutrality toward them, or attempt to curb them. ${ }^{32}$ In the remainder of this Article, I describe and analyze a number of situations in which the legal system should concern itself with separating power over children and creating real checks and balances among those who share in this power..$^{33}$ At times, current legal structures effectively main-

${ }^{28}$ See Arlene F. Saluter, Current Population Reports, Special Studies Series P-20, No 461, Marital Status and Living Arrangements: March 19914 tbl F (US Dept of Commerce, Bureau of the Census, 1992). See also Barbara Dafoe Whitehead, Dan Quayle Was Right, The Atlantic 47, 50 (April, 1993) (describing the dramatic increase in the U.S. divorce rate beginning in 1965).

${ }^{29}$ See Whitehead, Dan Quayle was Right at 50 (reporting an increase in the out-ofwedlock birth rate from 5 percent in 1960 to 27 percent in 1990); Bruce A. Chadwick and Tim B. Heaton, eds, Statistical Handbook on the American Family 105 (Oryx, 1992) (reporting similar data and attributing it to a decline in the marriage rate rather than an increase in birth rates).

30 Professor Devins reports that, since 1982, thirty-four states have adopted statutes regulating home schooling. Neal Devins, Fundamentalist Christian Educators v. State: $A n$ Inevitable Compromise, 60 Geo Wash L Rev 818, 819 \& n 6 (1992). I assume that passage of these statutes corresponds to an increase in the number of children schooled at home.

31 Although there may well be significant racial or ethnic differences on questions of family arrangements and community response to them, see Gary B. Melton, Children, Families, and the Courts in the Twenty-First Century, $66 \mathrm{~S}$ Cal L Rev 1993, 2013-24 (1993), I believe that the general framework articulated in this Article is relevant without regard to those differences. All children should be reared in regimes of separated power.

32 Professor Dan-Cohen's analysis, arguing that greater resistance to change characterizes situations of role proximity compared to those involving role distance, suggests that familial relations are not easily changed by law. See Dan-Cohen, $61 \mathrm{U}$ Chi L Rev at 1231-1232 (cited in note 1).

${ }^{33}$ I am well aware that the approach I describe could be categorized as masculinist, primarily because of its emphasis on separateness and conflict rather than interconnectedness and bonding. See, for example, West, $55 \mathrm{U}$ Chi L Rev at 2 (cited in note 10); Minow, 1985 Wis $L$ Rev at 884-94 (cited in note 10) (describing how women brought family values of nurturing and connectedness into the larger world of governance). To this charge, if it comes, I must plead in confession and avoidance. I believe that every family is marked by both connectedness and separateness for members of both genders (whether or not at the same level for members of each gender). Yet domination-the danger against which power separation is aimed-may follow at least as much from the dark side of connectedness as from any other force in the family. I therefore do not see my approach as masculinist or antifeminist; I do see it as child-oriented, as I later claim in the discussion of joint custo- 
tain power separation; at others, the goal is ignored. In some cases, of course, it is very difficult even for one committed to power separation to describe how best to allocate power. Typically, these cases raise the question of precisely who should count as a family member or other interested party among whom power (and responsibility) should be distributed.

Finally, and crucially, I bring the question of the child's perspective into the analysis. It would be foolhardy to fret about separating power over children if the result were to force those children into regimes of authority so riddled with combat, confusion, and inconsistency that the results are destructive. Indeed, separation of powers in government protects negative liberty better than positive liberty precisely because such separation requires coordination and thereby makes action more difficult. Children, however, need positive guidance as well as freedom from harm. Whether and when power separation is worth the danger of gridlock or intolerable disharmony between authorities in a child's life is a question that I will attempt to address and answer.

\section{APPLying THE MODEL OF POWER Separation}

\section{A. Internal Restraints: Checks and Balances within the Family}

The initial problem for any effort to establish power separation and a healthy system of checks and balances within the family is to prescribe the optimum number of power holders. The most obvious answer is that one is not enough. ${ }^{34}$ If the one per-

dy. See text accompanying notes 43-68. I should add here that, from my perspective, the feminist work in family law is among the most original work in the field in the past fifty years. For a comprehensive view of the various kinds of arguments family law invites, see Carl E. Schneider, Moral Discourse and the Transformation of American Family Law, 83 Mich L Rev 1803 (1985).

${ }^{34}$ Single parenthood, at least for the young and uneducated, is a recipe for disaster. See Center for the Study of Social Policy, Kids Count Data Book: State Profiles of Child Well-Being 13 (Annie E. Casey Foundation, 1993) (suggesting a poverty rate ten times as high for children of single mothers who had their first child before age twenty, outside of marriage, and without finishing high school, compared to the children of mothers who had their first child after twenty, after high school graduation, and within marriage). See also Irwin Garfinkel and Sarah S. McLanahan, Single Mothers and their Children: A New American Dilemma 11-43 (Urban Institute, 1986) (suggesting that children in households with multiple adults fare better than children in households in which their mother is the only adult); Arthur J. Norton and Paul C. Glick, One Parent Families: A Social and Economic Profile, 35 Family Relations 9 (1986) (presenting evidence that single-parent families are socioeconomically disadvantaged compared to two-parent families); David T. Ellwood, Poor Support: Poverty in the American Family 128-88 (Basic Books, 1988) (analyzing problems of poverty in the single-parent family); William Galston, A Liberal-Demo- 
son with power is not wealthy, he will have to be both a worker and nurturer in order to avoid some combination of poverty, debilitating dependence on the state, and infliction of emotional harm upon his children. The strains of either work or nurturing can be overwhelming; the pressures of both are far too much for most of us to handle. And, wealthy or not, in a single-custodian family the only internal restraint is self-restraint, and children should not be made to depend on that alone.

A presumption against single-parent families as a matter of policy, however, is hardly an uncontroversial proposition. States may no longer add to the stigma of nonmarital birth by imposing legal disabilities on nonmarital children. ${ }^{35}$ More generally, our constitutional tradition severely limits the power of the state to regulate many aspects of family affairs and reproduction. ${ }^{36} \mathrm{Co}-$ ercive regulation of matters of such intimate and deep concern will always raise troubling questions of totalitarian control over citizens' lives and invidious discrimination against those who deviate from prevailing social norms. ${ }^{37}$

We should therefore put to one side any possibility of forbidding the creation and maintenance of single-parent families. Attempts at coercion will always be ridiculously impractical and will founder on what has become a longstanding element of our constitutional tradition. ${ }^{38}$ Nevertheless, if some number of par-

cratic Case for the Two-Parent Family, 1 Responsive Community 14 (1990-91) (discussing economic and psychological harms stemming from single-parent situations); Whitehead, Dan Quayle was Right at 47-48 (cited in note 28). But see Elaine A. Blechman, Are Children with One Parent at Psychological Risk? A Methodological Review, $44 \mathrm{~J}$ Marriage \& Family 179 (1982) (suggesting that the data on psychological risk is inconclusive).

$\mathrm{My}$ argument, moreover, is not limited to the poor. Even in affluent, middle-class families, single parenthood renders children more vulnerable to domination by an overbearing parent and neglect by an inattentive one.

${ }^{35}$ Levy $v$ Louisiana, 391 US 68 (1968) (state may not discriminate against illegitimate children); Glona v American Guarantee \& Liability Insurance Co., 391 US 73 (1968) (state may not discriminate against the mother of an illegitimate child).

36 See Skinner v Oklahoma, 316 US 535 (1942) (state may not sterilize habitual larcenists when it does not sterilize habitual embezzlers or other white-collar criminals); Griswold $v$ Connecticut, 381 US 479 (1965) (state may not prohibit married couples from using contraceptives); Roe $v$ Wade, 410 US 113 (1973) (sharply limiting state's ability to regulate or prohibit abortions); Planned Parenthood of Southeastern Pennsylvania $v$ Casey, 112 S Ct 2791 (1992) (reaffirming Roe's central holding that states may not prohibit previability abortions).

${ }^{37}$ See Jed Rubenfeld, The Right of Privacy, 102 Harv L Rev 737, 788-90 (1989) (arguing that state control over reproduction is dangerous because it gives government totalitarian power over citizens' life plans).

${ }^{38}$ Robert Bork is not on the Supreme Court today in part because he rejected this proposition. See Ethan Bronner, Battle for Justice: How the Bork Nomination Shook America 221-22, 260 (Norton, 1989) (describing the controversy over Bork's view of consti- 
ent-custodians greater than one is optimal for children, questions remain of what that number is and what, if anything, the law might do to create incentives toward that number. ${ }^{39}$

Because family arrangements are never entirely independent of cultural circumstances and economic conditions, it is difficult to reason abstractly about the optimum number of parents. Nevertheless, deeply embedded patterns of Western life suggest that the ideal of the two-parent family, surrounded by supportive but legally disempowered relatives and friends, reflects some deep wisdom about optimal arrangements for child welfare. This ideal is not a simple extrapolation from the facts of human reproduction. Rather, the ideal of the two-parent family reflects a variety of concerns that are quite independent of that biology.

Indeed, I wish to make it as clear as possible that I am not speaking here of the traditional nuclear family, which definitionally includes two adults of opposite sexes married to one another. For purposes of power separation, it does not matter whether the parents are married, although of course it matters whether they are committed to their children. Moreover, the concern for power separation is indifferent to parents' sexual preferences or gender; two parents of the same sex are preferable to one of either sex. ${ }^{40}$

Two-parent families-in a regime in which all adults are respected as equals-offer characteristics that make them, on average, the optimal setting for rearing children. ${ }^{41}$ Unanimous

tutional protection for reproductive autonomy and privacy).

39 The case law suggests that government-created incentives toward particular reproductive or family-forming decisions stand on a sounder constitutional footing than government coercion to the same ends. See Harris v McRae, 448 US 297 (1980) (neither the states nor the federal government are constitutionally obliged to fund abortions); Califano $v$ Jobst, 434 US 47 (1977) (Congress may terminate Social Security benefits of a disabled dependent child when the child marries); Rust $v$ Sullivan, 500 US 173 (1991) (Congress may prohibit projects supported by federal funds from giving abortion advice or counseling).

40 For an approving discussion of adoption by gay and lesbian couples, see text accompanying notes 77-81.

41 In the world of government, the basic structure of American democracy insists on three branches. If we are to follow through on the power separation analogy, should we strive to promote, through law and policy, the three-parent family? I do not think so. The world of families with children cannot be analogized to the affairs of state at this level of detail. First, major decisions concerning child welfare-for example, those involving education or medical treatment-may require unanimity among custodians. Although some such decisions may, in emergency situations, be authorized by one custodian, any one custodian may, in ordinary situations, veto such a decision. Each time we add a custodian for a child, we drive up the costs of obtaining unanimity. Custodians may hold out, either in good-faith disagreement or in strategic bargaining designed to advance ends 
decision making will be far easier with two parents than with any larger number, since decision-making transactions and their costs will be limited in number and manageable in scope. Two parents may bring different perspectives, on matters of fact as well as value, to the decision-making process. Though more than two parents obviously further increases the sources of information and perspectives, additional parties also render agreement and compromise too difficult. Most important for my purposes, two-parent arrangements create the maximum incentive and occasion for adults to monitor one another's treatment of children in the household-each will know that if she does not do so, there is no one else who can. Adding parents beyond two for the same child may invite shirking and overdependence by each parent upon the others; such a structure is likely to create fissures into which many children may fall.

Of course, not all two-parent families will behave so as to guarantee optimum child welfare. Two-parent families may be dysfunctional in a wide variety of ways, many of which will produce conflict that is destructive for children. And one-parent families will presumably be more free of this sort of conflict than will their two-parent counterparts. If my analysis of the dangers of self-referential behavior and the advantages of mutual monitoring by parents is sound, however, two-parent arrangements will, on average, prove superior.

The frequency and quality of two-parent families will depend most on nonlegal forces and norms, but there are margins within which the law may make a difference. ${ }^{42}$ Those margins should

other than child welfare. Of course, the state may intervene to force a decision when custodians have bargained to impasse, but this is hardly an optimal solution; the child may suffer significant harm before any state-triggered processes have been completed.

This may be the best ground, though not the one upon which the Supreme Court relied, for upholding the antipolygamy result in Reynolds $v$ United States, 98 US 145 (1878). In any event, as we know from Reynolds as well as more recent cases, the Constitution does not require states to create opportunities for three-parent families. See, for example, Michael H. $v$ Gerald D., 491 US 110 (1989) (states need not allow a putative father to assert paternal rights to a child born to an intact marriage).

One might solve the problem of multiple custodians by shedding all practices or rules requiring unanimity: in the case of three or more custodians, a simple majority might be permitted to govern. But this too has severe problems as a mechanism for resolution of family disputes. Dissenters may have trouble living with and supporting a decision with which they profoundly disagree, and may behave in ways that undermine it. Moreover, the number of custodians may be even rather than odd, and therefore present a tie-breaking problem. Extrafamilial resolution mechanisms might be a solution in some instances, but they will frequently entail cost and delay, and it is not hard to see why few custodians would be inclined to settle for the decision of an impersonal arbitrator on matters of child welfare.

42 Professor Dan-Cohen's analysis suggests that making a difference in these matters 
be addressed by what I will call the presumption of power separation in matters affecting the care and custody of children. As I have just argued, legal decision makers should, as an initial matter, prefer two custodians to one. Government-created incentive structures that affect family arrangements should be similarly designed to encourage and facilitate two-parent families.

The presumption of power separation has several corollaries. Although two is the optimum number for general-purpose custodians of children, a network of caring adults can improve the decisions of custodians and the lot of their wards. Thus, decision makers should, absent very good reasons to the contrary, prefer visitation to nonvisitation by those adults with a demonstrable interest in the child's welfare. And, for a set of reasons developed in Section III.B. below, legal policies, institutions, and decisions should be structured to increase the likelihood of involvement of significant extrafamilial forces in the major concerns of a child's life.

A wide variety of questions of law and policy might be affected by application of the presumption of power separation. What holds together these questions, and the responses I offer to them, is a view of children as constantly subject to one or more mediating institutions. These institutions are instruments through which state policy is accomplished even while they may shield the child from the full brunt of that policy. Children are rarely isolated actors in the state's eyes; they always belong to, or are in the care of, some person, entity, or agency. The law's best strategy for protecting children's interests is therefore the structural one of ensuring that these institutions of care are designed in ways adequate to their child-protecting and child-developing tasks. Separation of powers within and between such institutions is a key element in that design.

\section{Issues of child custody.}

The wisdom of joint custody of minor children after a divorce is an issue of considerable controversy in contemporary social policy. Joint custody, known to American law only in the past quarter century, presumes that parenthood continues even after marriage ends. Joint custody is therefore designed to maximize

will be difficult, but that the differences made are likely to stick. See Dan-Cohen, $61 \mathrm{U}$ Chi L Rev at 1231-33 (cited in note 1). 
the involvement of both parents in crucial decisions of child welfare.

"Joint custody" has two legal meanings. One is joint physical custody, in which parents who are divorced and living apart share a roughly equal division of custodial time and responsibility, as in the case in which children spend every other week in the household of each parent. ${ }^{43}$ The other meaning of "joint custody"-joint legal custody-refers to an arrangement in which parents have equal legal authority to make decisions affecting their children's well-being. ${ }^{44}$

Although most states have joint custody statutes, there are wide variations among them. They range all the way from states that permit joint custody only when both parents and the court agree, to states that have a presumption for joint custody, regardless of party consent, from which the divorce court can depart only by articulating a justification. ${ }^{45}$

Joint custody, particularly when it takes both physical and legal forms, is a paradigmatic illustration of the separation-ofpowers mechanism at work. When a two-parent family dissolves, the legal system faces a fundamental decision whether to abandon or maintain some version of strong power separation over children. In its allocation of custodial authority, both physical and legal, to a single parent, a sole-custody arrangement abandons the concern for power separation. Joint custody, both physi$\mathrm{cal}$ and legal, reverses that result; it is an attempt to maintain and foster a child's relationship with both parents after a divorce. When joint-custody decrees are in operation, the family has changed its form from that which existed pre-divorce, but has continued a regime of dual and separated power over the children. To preserve the child-protecting values of that separation, a presumption of joint custody-both physical and legal-of minor children from the dissolved marriage should be maintained. ${ }^{46}$

43 See Jana B. Singer and William L. Reynolds, A Dissent on Joint Custody, 47 Md L Rev 497, 503 (1988).

14 Id at 503-04.

4 See Andrew Schepard, Taking Children Seriously: Promoting Cooperative Custody After Divorce, 64 Tex L Rev 687, 702 \& nn 57-60 (1985). See also Beverly Webster Ferreiro, Presumption of Joint Custody: A Family Policy Dilemma, 39 Family Relations 420, 420-21 (1990).

${ }_{16}$ For an argument to this effect on constitutional grounds, see Holly L. Robinson, Joint Custody: Constitutional Imperatives, 54 U Cin L Rev 27 (1985) (arguing that the constitutional right to autonomy on issues of procreation necessarily creates a constitutional right to continued parental rights and custody). 
Of course, power separation through joint custody after divorce is profoundly different from the "joint custody" in an intact, two-parent family. In a well-functioning family, bonds of trust, cooperation, fidelity, and mutual commitment facilitate the productive operation of power separation dynamics. In such circumstances, both parents can see the intervention of the other in decisions concerning the children as based on a good-faith concern for child welfare. When those bonds are frayed or destroyed by divorce, the same intervention may be perceived as an attempt to use parental power as a weapon against the ex-spouse.

The conflicts that joint-custody arrangements, both physical and legal, may engender, and the developmental consequences of those conflicts for children of divorce, have given rise to two related lines of criticism of presumptions in favor of joint custody. One source of such criticism has arisen on feminist grounds. These critics argue that the imposition of joint custody of any kind without both parents' consent is unfair to women because it devalues their pre-divorce investment in nurturing and reduces their legal endowment in the probability of winning sole custo$\mathrm{dy}^{47}$ They further maintain that this devaluation contributes to the feminization of poverty by reducing women's leverage in bargaining with their ex-husbands to obtain an adequate divorce settlement or sufficient child support. ${ }^{48}$

There is doubt about the empirical validity of the latter point. ${ }^{49}$ Whatever truth there may be in this critique, however, it represents essentially a feminist, and not a "childist," perspective. ${ }^{50}$ The criticism focuses on the condition of adult women and

47 See Martha L. Fineman and Anne Opie, The Uses of Social Science Data in Legal Policymaking: Custody Determinations at Divorce, 1987 Wis L Rev 107, 118-24; Martha Fineman, Dominant Discourse, Professional Language, and Legal Change in Child Custody Decisionmaking, 101 Harv L Rev 727, 768-74 (1988). See also Joanne Schulman and Valerie Pitt, Second Thoughts on Joint Child Custody: Analysis of Legislation and its Implications for Women and Children, 12 Golden Gate U L Rev 538 (1982); Anne Marie Delorey, Joint Legal Custody: A Reversion to Patriarchal Power, 3 Canadian J Women \& L 33 (1989). But see Katharine T. Bartlett and Carol B. Stack, Joint Custody, Feminism, and the Dependency Dilemma, 2 Berkeley Women's L J 9 (1986) (suggesting that joint custody can release women from traditional gender roles and expand women's opportunities through shared parenting and responsibilities).

48 See Fineman, 101 Harv L Rev at 760-61; Singer and Reynolds, $47 \mathrm{Md} \mathrm{L} \mathrm{Rev} \mathrm{at}$ 514-15 (cited in note 43); Richard Neely, The Primary Caretaker Parent Rule: Child Custody and the Dynamics of Greed, 3 Yale L \& Policy Rev 168, 177-79 (1984).

49 See Maccoby and Mnookin, Dividing the Child at 154-59 (cited in note 25). Maccoby and Mnookin found no "statistically persuasive evidence" to support the claim that mothers "had to give up support to win the custody they wanted." Id at 156.

so I am not alone in this observation. See, for example, Schepard, $64 \mathrm{Tex} \mathrm{L}$ Rev at 775 (cited in note 45 ). 
their position relative to adult men; ${ }^{51}$ only derivatively does it take into account the overall welfare of children. Of course, if one has a gender bias that leads to stereotypical generalizations about nurturing women and non-nurturing men, ${ }^{52}$ then enhancing women's custodial rights is quite in line with child protection. But if that bias is deemed inadmissible, as I believe it should be on constitutional as well as policy grounds, ${ }^{53}$ the feminist critique of joint custody appears quite misguided. ${ }^{54}$

A child-centered view of the problem of custody must transcend the male vs. female oppositionalism typical of the feminist critique. From the separation-of-powers perspective, it is not the power dynamic between male and female adults that is most important. Rather, to the child, custody is primarily about power over him. From the child's perspective, women are far from powerless; like men, they are a source of power to do well or badly by their wards. ${ }^{55}$ Thus, the feminist critique here misses an important dimension.

When the feminist critique moves on to the relationship between custody arrangements and child welfare, it moves into more fertile territory. Feminist legal theory frequently stresses responsibility over rights. ${ }^{56}$ In matters of custody, such argu-

s1 See generally Catharine MacKinnon, Feminism Unmodified 21-77 (Harvard, 1987).

52 For an explicit example of such bias, see Martha Albertson Fineman, Intimacy Outside of the Natural Family: The Limits of Privacy, 23 Conn L Rev 955, 970-71 (1991) (suggesting mother and child as the core family unit).

${ }_{53}$ See Reed $v$ Reed, 404 US 71, 76 (1971) (holding that a state may not apply a presumption giving preference to males over females in administering decedents' estates); Craig $v$ Boren, 429 US 190, 204 (1976) (Equal Protection Clause is violated when states rely on overbroad and stereotypical generalization about the sexes in forming policy). The Supreme Court's decision in Michael M. $v$ Sonoma County Superior Ct., 450 US 464, 47275 (1981), suggests that biological differences between men and women may justify statesponsored gender discrimination. The evidence of female biological superiority in childrearing, however, is weak or nonexistent. See Ruth Hubbard, The Politics of Women's Biology 117-18, 123-29 (Rutgers, 1990).

54 Professor Scott's critique is more subtle, relying as it does on the notion of preserving pre-divorce family arrangements in creating the post-divorce family. See Elizabeth S. Scott, Pluralism, Parental Preference, and Child Custody, 80 Cal L Rev 615 (1992). See also Elizabeth Scott and Andre Derdeyn, Rethinking Joint Custody, 45 Ohio St L J 455 (1984). I disagree with Scott and Derdeyn on three major points: they do not give enough weight to the ways in which divorce is likely to transform preexisting parent-child relationships, whatever their former shape; they underestimate the costs and difficulties of proving the actual pre-divorce arrangements in all but the most traditionally structured families; and they underweight the power separation concerns.

is See, for example, John Hart Ely, The Wages of Crying Wolf: A Comment on Roe v. Wade, 82 Yale L J 920, 934-35 (1973) (suggesting that women may be a "discrete and insular minority" when compared with men, but not when compared with fetuses).

${ }^{36}$ See, for example, Katharine T. Bartlett, Re-Expressing Parenthood, 98 Yale L J 293, 297-306 (1988); Elizabeth M. Schneider, The Dialectic of Rights and Politics: Perspec- 
ments are especially well targeted; adult "rights" with respect to children are frequently conceptualized as rights against the rest of the world, not against the children themselves. ${ }^{57}$

When custody is viewed as centered upon responsibility to children rather than parental rights against other adults, the feminist critique and a more general empiricist critique of joint custody, both physical and legal, begin to converge around the concern that nonconsensual joint-custody arrangements produce conflict that is excessive and harmful to the child. In their significant recent work, Dividing the Child, Professors Maccoby and Mnookin counsel against a presumption of joint physical custo$\mathrm{dy},{ }^{58}$ instead recommending "cautiously" in favor of a presumption of joint legal custody. ${ }^{59}$ In general, their data support the intuitive proposition that joint custody of any kind tends to work best when the parents communicate well, do not harbor intense hostility toward one another, and are in reasonably close agreement on basic values. Not surprisingly, joint custody tends to work least well when those qualities are missing. In such cases, the danger that children will be used and abused as pawns in their parents' continuing struggle is at its highest. ${ }^{60}$

The central problem for the legal system might therefore be defined as follows: how can decision makers predict, at the time of divorce, which parents will be capable of making a healthy adjustment to joint custody? At the time of this decision, the tensions and hostilities thought to impede joint custody are likely to be at their apex. Which families will experience continued and intense hostilities, and which will ultimately develop a new sense of normalcy, is very difficult to predict.

Does this uncertainty argue against a presumption for joint custody? I think not. First, the problem of predictive uncertainty haunts any standard by which courts could award custody of

tives from the Women's Movement, 61 NYU L Rev 589 (1986).

${ }_{57}$ Bartlett, $70 \mathrm{Va} L \mathrm{Rev} 879,883-84$ (cited in note 5) (enumerating the exclusive rights of parenthood, almost all of which operate against third parties to the possible detriment of the child).

68 Maccoby and Mnookin, Dividing the Child at 284-85 (cited in note 25).

59 Id at 289. In particular, Maccoby and Mnookin approve joint legal custody's implication that both mothers and fathers "have rights and responsibilities with respect to their children after divorce." Id.

${ }_{60}$ Id at 284-85, 291. See also Judith S. Wallerstein and Janet R. Johnston, Children of Divorce: Recent Findings Regarding Long-Term Effects and Recent Studies of Joint and Sole Custody, 11 Pediatrics in Rev 197, 201-03 (1990); Janet R. Johnston, Marsha Kline, and Jeanne T. Tschann, Ongoing Postdivorce Conflict: Effects on Children of Joint Custody and Frequent Access, 59 Am J Orthopsychiatry 576, 588-91 (1989); Gary N. Skoloff, Joint Custody: A Jaundiced View, Trial 52, 53 (March 1984). 
children. ${ }^{61}$ No one has devised anything resembling a system that inspires confidence in its outcomes. As a consequence, solecustody placements may easily turn out to be serious errors, either because sole custody drives a wedge between the noncustodial parent and the child, or because the custodial parent does a poor job, or both.

Second, joint custody has separation-of-powers virtues, while sole custody does not. Professors Mnookin and Maccoby invoke the Solomonic image of dividing the child to represent metaphorically the harm of joint custody. But if one conceives of the intact two-parent family as a grouping in which power over children is already separated, then joint custody becomes just another way of maintaining power separation-albeit under new dynamics-rather than a sword for dividing children.

Third, children may be more in need of monitors of parental (mis)behavior after divorce than at any other time. As they work through the trauma of divorce, parents may be inclined toward possessive treatment of their children, with all of the dangers of domination that treatment suggests. Because they lack physical proximity, divorced parents cannot monitor one another as effectively as before; ${ }^{62}$ still, they will have psychic incentives to monitor more intensely. If the parents' energy can be redirected away from the conflict with the other parent and toward the child, the parents may communicate to the child a focused concern for her welfare that may not have been so obvious prior to the divorce.

Fourth, a court can easily alter a joint custody decree if either parent abuses her custodial privilege. Thus, parents in a joint custody arrangement must both be on guard lest they jeopardize their custody status. Because it is a smaller move to shift

61 The general standard that placements should be in "the best interests of the child" has provoked substantial criticism because of the unpredictability and inconsistency in its application. See, for example, Robert H. Mnookin, Child-Custody Adjudication: Judicial Functions in the Face of Indeterminacy, 39 L \& Contemp Probs 226 (Summer 1975); David L. Chambers, Rethinking the Substantive Rules for Custody Disputes in Divorce, 83 Mich L Rev 477 (1984); Robert H. Mnookin and Lewis Kornhauser, Bargaining in the Shadow of the Law: The Case of Divorce, 88 Yale L J 950, 969-71, 977-80 (1979); Jon Elster, Solomonic Judgments: Against the Best Interest of the Child, 54 U Chi L Rev 1 (1987); Joseph Goldstein, Anna Freud, and Albert J. Solnit, Beyond the Best Interests of the Child 53-67 (Free Press, 2d ed 1979). The "primary caretaker" standard, more popular among feminists, see, for example, Fineman, 101 Harv $L$ Rev at 768-74 (cited in note 47), is arguably more predictable in terms of judicial outcomes, but arguably no more predictive of good results because it elevates historical patterns of care giving over concerns of how children will fare in a family reshaped by divorce. There is no guarantee that the historical pattern was functional or will continue to be functional in the changed circumstances.

62 See Maccoby and Mnookin, Dividing the Child at 39 (cited in note 25). 
from joint custody to sole custody than to reverse custodians entirely (as would be required if a parent with sole custody were acting against the child's best interests), domestic-court judges may be disinclined to protect joint-custody arrangements that either parent is abusing. And loss of custody, even in its partial form, is painful and stigmatizing, so parents who want to remain close with their children will make efforts to avoid the risk.

Fifth, a presumption of joint custody expresses society's appropriate aspirations and concern for its children and recognizes their need for guidance and protection after their parents' divorce, when that need is likely to be greatest. Divorce causes trauma to children, and their parents have inflicted it. What better healing device, and what better source of reassurance to children that they have not lost their parents, than to maintain their physical and legal relationship to both parents to the fullest extent possible? ${ }^{63}$

Sixth, joint physical custody is a direct way to involve the time and energy (not just the money) of both parents in their children's lives. When one parent is rearing children while the other parent pays support and does not have custodial responsibility, the payor will be tempted to carp and criticize the recipient's child-rearing practices; the dynamics of power separation are likely to be rather different when both parents have equal power, responsibility, and opportunity to rear their children and to observe the other parent do the same.

Moreover, under a presumption of joint physical custody, a father or mother who successfully resisted custodial responsibility would presumably have to pay the other to accept a larger share of it. Indeed, I would add a stress premium to such a "playor-pay" rule, designed to compensate the sole custodian and the child for the extra emotional difficulty incurred in sole custodial arrangements. This structure of substitute responsibilities would appropriately reinforce the notion that being a parent is a shared and continuous commitment, unbroken by divorce. ${ }^{64}$ Explicit linkage between denial of custodial responsibility and increase in

63 Professor Dan-Cohen's article argues explicitly what anyone who has experienced divorce in a family with minor children already knows-that significant "damage to self results from losing a proximate role ...." Dan-Cohen, $61 \mathrm{U}$ Chi L Rev at 1238 (cited in note 1). The presumption of joint custody is designed to limit that damage.

${ }_{64}$ Professor Karen Czapanskiy's reconceptualization of the "ideal parent" reflects a view of joint parental responsibility that is similar to my own. Karen Czapanskiy, Volunteers and Draftees: The Struggle for Parental Equality, 38 UCLA L Rev 1415, 1463-71 (1991). 
financial responsibility may discourage the former, thereby serving power separation values.

Of course, as many commentators have pointed out, joint custody is not the best solution for all families. Policymakers and judges must confront important and difficult questions about what justifications are sufficient to overcome the presumption of joint custody. Decisions must inevitably proceed case by case, with the paramount concern being the likelihood that the parents will, over time, engage in sustained and destructive conflict of the sort that is likely to cause lasting harm to the children. ${ }^{65} \mathrm{Un}$ questionably, a lengthy history of physical violence between the parents is an indicator that joint custody is an inappropriate disposition. ${ }^{66}$ Moreover, the age of the children might well affect the weight of the presumption; the younger the child, the less he is likely to be able to withstand high-intensity conflict without suffering emotional difficulty. Either parent's resistance to the arrangement, however, should not be sufficient to bootstrap the resister out of the presumption's force; to allow nonconsent to serve this function is to give a premium to announced refusal to cooperate in what was begun as a joint venture in childrearing. ${ }^{67}$ Divorce does not end the parental relation, and so it should not per se empower either parent to terminate that aspect of the joint venture.

I would thus reorient the conclusion in Dividing the Child that "in those cases where the parents are involved in bitter dispute ... a presumption for joint [physical] custody would do harm." ${ }^{\text {"68 }}$ That assessment of the consequences to a child caught in a "bitter dispute" does not warrant a complete rejection of joint

65 See Maccoby and Mnookin, Dividing the Child at 284-85 (cited in note 25); Ferreiro, 39 Family Relations at 424 (cited in note 45); Andre P. Derdeyn and Elizabeth Scott, Joint Custody: A Critical Analysis and Appraisal, 54 Am J Orthopsychiatry 199, 204 (1984); Scott, 80 Cal L Rev at 632 (cited in note 54); Scott and Derdeyn, 45 Ohio St L, $\mathrm{J}$ at 484-88 (cited in note 54); Johnston, Kline, and Tschann, 59 Am J Orthopsychiatry at 588-90 (cited in note 60); J. Rainer Twiford, Joint Custody: A Blind Leap of Faith?, 4 Behavioral Sci \& L 157, 162 (1986).

${ }_{66}$ As my colleague Naomi Cahn has persuasively argued, a pattern of repeated physical violence against one parent by the other is a very strong reason to alter custody or visitation arrangements. See Naomi R. Cahn, Civil Images of Battered Women: The Impact of Domestic Violence on Child Custody Decisions, 44 Vand L Rev 1041, 1064-81 (1991).

67 Of course a parent who wanted sole custody might try to provoke conflict within a joint-custody arrangement as a way of showing its disutility in her case. To do so, however, might be to risk a cure worse than the disease-that is, a decision granting sole custody to the nonprovoker.

63 Maccoby and Mnookin, Dividing the Child at 284-85 (cited in note 25). 
physical custody. Maccoby and Mnookin would abandon the presumption, insofar as it favors joint physical custody, in all cases because the practice works out badly in some. The better approach is to maintain the presumption, allowing it to be overcome where the likelihood of sustained and serious conflict is great.

\section{Adoption by single parents.}

The problem of designing child-custody decisions so as to increase the likelihood of multiple custodianship is not limited to the relatively simple, though controversial, case of joint custody. The issue also arises every time a single person seeks to become a parent. For example, what view should the state take toward adoption by single parents or, in states where surrogacy arrangements are permitted, toward surrogacy contracts with single parents on each side?

The case of the single parent who seeks to acquire a child (through whatever means) starts with a problem: it is a proposed custodial arrangement lacking power separation. My solution is to give surrendering parents the option of retaining a parental interest-preferably joint legal custody but in any event visitation rights-in those instances in which single parents seek to adopt a child by traditional means ${ }^{69}$ or create one with the aid of a surrogate.

As things now stand, however, there is a tension between adoption law and surrogacy law in their respective receptivity to that solution. Adoption law has traditionally been hostile to the notion that surrendering parents retain any interest in visiting the child, or even in other, lesser contact. ${ }^{70}$ Surrogacy law, though much less developed, reveals the new, feminist-based concern for the continuing interest of the gestational mother in a post-partum relationship with her child. ${ }^{71}$

69 It is not unusual for states to explicitly recognize the right of a single adult to adopt. See, for example, NY Domestic Relations Law $\S 110$ (McKinney Supp 1994) ("An adult unmarried person or an adult husband and his adult wife together may adopt another person.").

${ }^{70}$ State adoption statutes typically provide that adoption results in termination of all rights in the biological parent. See, for example, Cal Family Code $\$ \$ 8617,9306$ (West 1994); NY Domestic Relations Law \& 117(1)(a) (McKinney 1988). These laws may, however, include explicit exceptions such as stepparent adoption. See, for example, Cal Family Code § 8548 (West 1994); NY Domestic Relations Law § 117(1)(d) (McKinney 1988).

${ }^{71}$ See In the Matter of Baby M, 109 NJ 396, 537 A2d 1227, 1263 (1988). For commentary on Baby $M$ and surrogate mothering, see generally Martha A. Field, Surrogate Motherhood (Harvard, 1988); Judith Areen, Baby M Reconsidered, 76 Georgetown L J 1741 (1988); Anita L. Allen, Privacy, Surrogacy, and the Baby, 76 Georgetown L J 1759 
There are a number of objections to expanding that idea into the general law of adoption. First, as Professor Bartholet argues in her recent book on adoption, any policy that disadvantages adoptive parents over otherwise comparable biological parents may reflect an unreasonable privileging of biological parenthood. ${ }^{72}$ There is something to this, but the solution is to equalize up rather than down; that is, all single parents should face circumstances designed to increase the likelihood of involvement of another parent. In all single-parent cases, biological and otherwise, the law should maximize the incentives for two-parent participation in childrearing. In the case of biological parents, these circumstances presumably should include aggressive pursuit of an absent parent for both financial support and parental engagement in the life of the child.

The gap between biological and adoptive parents, however, suggests a deeper set of questions about the role of incentives versus the role of coercion in maintaining two-parent families. Biological parents are obligated to support their offspring; when they attempt to leave the other biological parent with custody and all the responsibility, financial and otherwise, we do not permit such acts of abandonment to terminate the abandoner's obligations to the child. Why then should we let surrogates, or other relinquishing parents, effectively transfer all of their responsibilities to single adopters?

One might simply oppose adoption by single parents on this very ground-that it substitutes one parent for two and presumptively violates power-separation principles. $^{73}$ The obvious re-

(1988); John Lawrence Hill, What Does it Mean to be a "Parent"? The Claims of Biology as the Basis for Parental Rights, 66 NYU L Rev 353 (1991). See also Barbara Bennett Woodhouse, Hatching the Egg: A Child-Centered Perspective on Parents' Rights, 14 Cardozo L Rev 1747 (1993) (articulating and defending the concept of gestational father, which refers to a man who gives emotional support and comfort to a woman during pregnancy whether or not he is biologically related to the expected child). For a suggestion that surrogate mothers who surrender their contracted-for offspring not be permitted to retain a continuing parental interest, see Frances H. Miller, Surrogate Fatherhood?, 70 BU L Rev 169, 180 n 57 (1990), reviewing Martha A. Field, Surrogate Motherhood (Harvard, 1989).

${ }_{72}$ Elizabeth Bartholet, Family Bonds: Adoption and the Politics of Parenting (Houghton Mifflin, 1993). For the first wave of scholarly reaction to Professor Bartholet's intriguing arguments, see Naomi R. Cahn, Family Issue(s), 61 U Chi L Rev 325 (1994); Nancy E. Dowd, A Feminist Analysis of Adoption, 107 Harv L Rev 913 (1994).

${ }^{73}$ Depending upon the facts, single-parent adoption in some circumstances may be correctly viewed as substituting a single parent for no parents at all. For a discussion of single-parent adoptions, see William Feigelman and Arnold R. Silverman, Chosen Children: New Patterns of Adoptive Relationships 173-92 (Praeger, 1983); Vic Groze, Adoption and Single Parents: A Review, 70 Child Welfare 321 (1991); Victor K. Groze and 
sponse, however, is that moderate, pro-adoption incentives are surely desirable. Parents are much less likely to surrender if they remain obliged to support their offspring - that is, if they retain their duties but not their corresponding rights and powers. Because society wants to encourage adoption, at least up to a point, a moderate incentive structure has some merit. In contrast, no one sees any need to create incentives for the biological production of nonmarital children, or the relinquishment of obligations by one of their parents to the detriment of the child and the other parent. Because adoption requires surrender of rights by the more interested as well as the less interested biological parent, the law treats biological parents seeking to end their connections in favor of adoptive parents differently as compared to a similar relinquishment by one biological parent in favor of the other. $^{74}$

I do not propose to eliminate that gap entirely. I do suggest that a halfway solution-founded on the presumption of power separation-may be appropriate for adoptions by single parents. When single-parent adoption is the anticipated course at the time of relinquishment, surrendering parents might be given a choice between full and partial relinquishment of their parental rights. Full relinquishment would end all rights and obligations; partial relinquishment would keep in place both rights and obligations. Among these would be the obligation to help support the child, perhaps financially and perhaps emotionally. The rights might range along a continuum from those associated with joint legal custody to visitation to the right to receive regular information about the child's development. ${ }^{75}$

James A. Rosenthal, Single Parents and their Adopted Children: A Psychosocial Analysis, 72 Families in Soc: J Contemp Human Serv 67 (1991). Moreover, because biological fathers tend to be uninvolved in the pregnancy and adoption process, many adoptions may be viewed as substituting one or two adopting parents for a real-life prospect of only one truly involved biological parent.

${ }_{74}$ To eliminate the disincentive to artificial insemination that follows from tying responsibility to genetic relation to the child, state law has typically relieved anonymous sperm donors of such duties. See, for example, Or Rev Stat $\$ 109.239$ (1993); Cal Family Code $\S 7613$ (West 1994). The California provision requires that the insemination be performed by a licensed physician in order for sperm donors to be relieved of rights and responsibilities. For the consequences of sperm donation and insemination that does not use physician services, see Jhordan C. $v$ Mary $K$., 179 Cal App 3d 386, 224 Cal Rptr 530 (1986) (declaring sperm donor to be the legal father of a child born from artificial insemination).

${ }_{75}$ That is, state law might provide for a different bundle of so-called "open adoption" rights when single parents adopt than when two parents adopt. Of course, this cannot work in those cases in which biological parents relinquish their rights without knowing 
Perhaps few surrendering parents would choose partial relinquishment and would prefer instead to make a clean break with the child. And it may be that few adopting parents would find partial relinquishment desirable, particularly if it included any loss of control over the child. For those who would choose otherwise, however, the option of partial rights and responsibilities would create new dynamics in the adoption market, adding to the incentives of surrendering parents to do so and perhaps decreasing the number of abortions and increasing the number of children available for placement. It is at least imaginable that the option of acquiring an active co-parent through the adoption process, rather than suffering a complete loss of the child, would induce some women to become part of an adoption-generated family. If these changes occurred, they would open up new familial possibilities and further the policies behind the presumption of power separation, because they would maintain the legally protected interest of two adults in the child. ${ }^{76}$

\section{Gay parenthood.}

The separation-of-powers presumption can inform other issues as well. Consider the question of legal parenthood, by adoption or otherwise, for gay or lesbian couples. ${ }^{77}$ This has been a battleground in many places, ${ }^{78}$ and recent struggles over related issues of discrimination have only intensified the conflict. In a few communities, however, courts have begun to view such adoptions in a favorable light.

For example, in Adoption of Tammy, the Supreme Judicial Court of Massachusetts recently affirmed the grant of an adoption petition by a lesbian couple, one of whom was the biological

how many adoptive parents there will be, as might be the case when a child is surrendered to an agency for foster placement or later adoption. For a discussion of existing open-adoption schemes, which do not make such a one-parent/two-parent distinction, see Bartholet, Family Bonds at 53-58 (cited in note 72). Most open-adoption proposals are driven by the needs of adoptees to know their biological roots; those needs are not likely to be affected by the number of adopting parents.

76 Under such a scheme, subsequent marriage by the adopting parent would result in stepparent status for the new spouse. This status could only be changed by death of the surrendering parent, termination of her rights, or voluntary relinquishment of those rights, followed by a successful adoption petition from the stepparent.

77 See generally Nancy Polikoff, This Child Does Have Two Mothers: Redefining Parenthood to Meet the Needs of Children in Lesbian-Mother and Other Nontraditional Families, 78 Georgetown L J 459 (1990).

${ }_{78}$ Id at 462-63. For a recent journalistic account, see William A. Henry III, Gay Parents: Under Fire and on the Rise, Time 66 (Sept 20, 1993). 
mother of the child. ${ }^{79}$ In a four-to-three decision, the court ruled that the relevant Massachusetts statutes permitted an adoption petition under these circumstances-that is, from a same-sex couple including a natural parent who had preexisting legal rights and duties with respect to the child. ${ }^{80}$

My focus on the outcome in Tammy, which I applaud, is less upon the sexual orientation of Tammy's parents and more upon their number. Had the court denied the adoption, Tammy would have been left with a biological mother and her mother's partner as a de facto second parent. In this role, the partner may well have functioned quite effectively, operating as an equal with Tammy's biological mother. The symbolism of the adoption process, however, when coupled with the rights and responsibilities it creates, may well deepen the partner's commitment to Tammy. Moreover, if Tammy's biological mother should die, become unfit to be a parent, or abandon her child, Tammy would still have a legally recognized parent. And, in the event that the adult partners separate, Tammy will still have two parents, with the possibility of joint custody of Tammy as a parenting option. In short, approving the petition advances Tammy's interests in many ways, not least by creating a legally recognized two-parent fami$1 \mathrm{y}{ }^{81}$

\section{Visitation rights for nonparents.}

The scope of visitation rights for nonparents is another family-law context in which the presumption of power separation, and its corollary principle of multiple influences in children's lives, can inform legal analysis. The rate of divorce and the loss of parents through other family-altering events has left many children

79516 Mass 205, 619 NE2d 315 (1993). The biological mother had become pregnant as a result of artificial insemination; consequently, the adoption proceeding did not involve terminating the parental rights of the biological father, who under state law had none. Professor Polikoff opens her analysis in This Child Does Have Two Mothers (cited in note 77), with a discussion of the lesbian couple who were the petitioners in Adoption of Tammy.

so 619 NE2d at 319.

${ }^{81}$ Consider M.D. v C.J., Nos DR-1366-93C, N-0268-91, and A-302-92 (DC Super Ct, Jan 7, 1994), reported in The Daily Washington Reporter 221 (Feb 4, 1994) (adoption ruling in favor of a foster parent in a lesbian partnership over a biological great-aunt). While the continuity of successful foster care was of great influence in M.D. $v$ C.J., the presence of a partner to the foster parent at least suggests the operation of the presumption of power separation. Moreover, the court's grant of generous visiting rights to the boy's extended biological family is consistent with the corollary principle, elaborated below, of multiple influence. 
with single custodians. Often these children lose contact with the extended family of the noncustodial parent(s), especially when the noncustodial parent has become estranged from the children. In such cases, the custodial parent may rebuff efforts by the noncustodial parent's family to maintain a relationship with the children. Many states have enacted legislation to create and protect a legal interest in grandparents' visitation rights, ${ }^{82}$ and Congress has expressed support for this trend. ${ }^{83}$

To enhance the goals of power separation-to provide monitoring and additional sources of fiscal and emotional support-policymakers should foster noncustodial as well as custodial influences in children's lives. Many people can provide such influences, including (as explored in Section III.B. below) people outside the family. Family influences are unusually important, however, because they are so likely to be accompanied by a sense of long-term commitment to a child. A grandparent or other noncustodial relative can be a source of guidance, care, love, and inspiration. Such a person also can monitor custodial (mis)behavior, is more likely than co-custodians to report such misbehavior to authorities, and may be able to act as a custodian when others fail. Thus, the movement in the law toward visitation rights for noncustodial relatives is fully consistent with the underlying concerns of the separation-of-powers principle. ${ }^{84}$

\section{Postdivorce religious differences.}

A very different example of the role of the separation-of-powers principle arises in the context of religion. When a child has two parents, religious differences between them may be a source of healthy checks and rich choices rather than destructive con-

82 See, for example, 750 ILCS $\$ 5 / 607$ (Smith-Hurd 1993). But see Bush v Squellati, 122 Ill 2d 153, 522 NE2d 1225 (1988) (holding that the Illinois grandparent visitation statute does not confer visitation rights to biological grandparents after a child has been given up for adoption by his biological parents). See also Cal Family Code $\S 3103$ (West 1994); $23 \mathrm{~Pa}$ Cons Stat Ann $\$ 5314$ (Purdon 1991).

83 HR Con Res 67, 99th Cong, 1st Sess (Feb 26, 1985), in 131 Cong Rec 714 (Feb 26, 1985) (urging states to develop and adopt a model act that extends visitiation rights to grandparents).

84 The movement is fully inconsistent, as is American visitation law generally, with the suggestion in Goldstein, Freud, and Solnit, Beyond the Best Interests of the Child at $38,116-21$ (cited in note 61 ), that the custodial parent have complete authority to deny visitation by noncustodians, parent or otherwise. Though Goldstein, Freud, and Solnit are correct that visitation should not be viewed in rights terms, id at 121 , it should be viewed in child-oriented structural terms. These considerations argue sharply against leaving control over visits to one whose own behavior will be monitored as a result of those visits. 
flict. In an intact family, the existence or extent of religious difference between parents is none of the state's concern. In the case of disputes between divorced parents over their children's religious upbringing, however, the state may be brought in as a dispute resolver. In such cases, the state must have a policy about the wisdom of multiple religious influences in children's lives. ${ }^{85}$

It is not hard to see how these disputes arise, or why they are unusually intense. Assume that a child has a single parent with physical and legal custody; this custodial parent, having committed the child to a program of religious training and experience, will expect the noncustodial parent to cooperate. ${ }^{86}$ Such cooperation may take affirmative form; for example, the custodial parent may expect the noncustodial parent to deliver the child to a religious activity. ${ }^{87}$ Alternatively, the noncustodial parent may expose the child to a contrary religious training or experience, and the custodial parent may want him to stop. ${ }^{88}$

These cases present difficult issues. Before divorce, both parents enjoyed a constitutional right to direct their child's religious upbringing. Does the loss of custody entail the loss of that right? Further, since the noncustodial parent clearly retains his own independent constitutional right to practice his religion, must he surrender or suspend it when his child is present?

One might expect that courts faced with this situation would hold that the custody award includes the exclusive right to control a child's exposure to religious influences. One might expect as well that judges would have the intuition that training in more than one religion will be particularly confusing or difficult

${ }^{85}$ For a general discussion of this problem, see Donald L. Beschle, God Bless the Child? The Use of Religion as a Factor in Child Custody Cases and Adoption Proceedings, 58 Fordham L Rev 383 (1989).

${ }^{86}$ In some circumstances, the parties' divorce agreement may make an explicit provision concerning their duties to cooperate on matters of religious training for their children. See generally Martin Weiss and Robert Abramoff, The Enforceability of Religious Upbringing Agreements, 25 John Marshall L Rev 655 (1992).

${ }_{87}$ See, for example, Zummo v Zummo, 394 Pa Super 30, 574 A2d 1130, 1157 (1990) (holding that a divorce order may require the noncustodial parent to deliver the children to a religious school).

${ }_{88}$ In some states, a divorce order may not prohibit the noncustodial parent from taking the children to religious services of his own faith during lawful visitation, absent a showing of physical or emotional harm to the children. Id at 1140. See also Andros $v$ Andros, 396 NW2d 917, 924 (Minn App 1986) (holding that a court may prohibit a noncustodial parent from exposing his children to religious services where continued conflict over the parents' religious differences could harm the children). 
for a child, or will further divide the child's loyalties in an already fractured situation.

The law has not developed along such simple lines, however. Rather, the substantive divide within this jurisprudence is on the question of what showing of harm to the child must be made before the noncustodian may be ordered to refrain from involving his children in his own religious activity during visitation time. Some courts are willing to permit such orders on a showing of a reasonable likelihood of future harm, and have included emotional harm in the calculus of what counts for this purpose ${ }^{89}$ Others are far more tolerant of the noncustodial parent's desire to involve his children in his religion, and refuse to restrain such activities unless there is a clear demonstration of present harm or a high probability of future harm. ${ }^{90}$ These latter decisions, more tolerant of the prospect of dual religious training, sometimes demand a showing of physical or other tangible harms before approving religious restraints on noncustodial parents. ${ }^{91}$

The decisions requiring graver, more immediate, and more readily demonstrable harm are, of course, more solicitous of the free exercise rights of the noncustodian, but they are better explained by the separation-of-powers principle. Religion may be a

89 See, for example, Miller $v$ Hedrick, 158 Cal App 2d 281, 322 P2d 231, 233 (1958) ("may be detrimental to ... the child"); Morris $v$ Morris, $271 \mathrm{~Pa}$ Super 19, 412 A2d 139, 147 (1979) ("probably result in some mental disorientation to [the child]"); Bentley $v$ Bentley, 86 AD2d 926, 448 NYS2d 559, 560 (1982); Andros, 396 NW2d at 922 ("will likely cause emotional damage (to the childl in the future"); In re Marriage of Short, 698 P2d 1310,1313 (Colo 1985) ("might reasonably imperil the physical or mental health of [thel child").

so For examples of courts requiring a clear showing of present harm, see Munoz $v$ Munoz, 79 Wash 2d 810, 489 P2d 1133, 1135 (1971) ("clear and affirmative showing" of harm); In re Marriage of Murga, 103 Cal App 3d 498, 163 Cal Rptr 79, 82 (1980) (evidence must show causal connection between teaching and mental harm); Khalsa $v$ Khalsa, 107 NM 31, 751 P2d 715, 721 (NM App 1988) (general testimony by mother insufficient); Hanson v Hanson, 404 NW2d 460, 464 (ND 1987) (same); Funk v Ossman, 724 P2d 1247 (Ariz Ct App 1986) (testimony by mother who was a psychologist found to be sufficient); Zummo, 574 A2d at 1155 ("substantial threat of ... physical or emotional harm"). For examples of courts rejecting merely speculative future harm, see In re Marriage of Mentry, 142 Cal App 3d 260, 190 Cal Rptr 843, 847 (1983); Zummo, 574 A2d at 1155.

91 See, for example, Quiner v Quiner, 59 Cal Rptr 503, 516 (Cal App 1967). These cases might be good candidates for the application of the "equal regard" principle, developed by Professors Eisgruber and Sager in their contribution to this Special Issue. See Christopher L. Eisgruber and Lawrence G. Sager, The Vulnerability of Conscience: The Constitutional Basis for Protecting Religious Conduct, 61 U Chi L Rev 1245 (1994). Specifically, judges in these cases might be enjoined to treat religious differences between divorced parents under the same standards of harm to children as would be applied to other disagreements concerning serious matters, such as training in music, foreign language, or other nonreligious aspects of culture. 
powerful force in a child's development. When one or both parents are intensely religious, there is a strong likelihood that religion will be influential in the child's life. Within a "mixed" marriage containing two deeply religious parents, each parent is likely to advance rigorously his own brand of religion and to monitor the extent of indoctrination in the religion of the other parent. This sort of behavior may cause religious confusion, but-consistent with the separation-of-powers principle-it equally may forestall domination of the child by either parent or either religious tradition.

When parents are divorced and both are committed to a religious life, the problem of the child's religious training becomes more acute. Because the parents are living separately, they are unable to directly monitor one another's religious messages to the child. If only one parent is free to provide religious training, an imbalance in favor of that parent's religious tradition is almost certain to develop.

Each case must of course be taken on its facts, and courts cannot dictate to families how many religions they should include in childrearing. But when two divorced parents press two different religious traditions upon a child, the view expressed in Zummo $v$ Zummo seems most persuasive:

We also emphasize that while the harm involved may be present or future harm, the speculative possibility of mere disquietude, disorientation, or confusion, arising from exposure to "contradictory" religions would be a patently insufficient "emotional harm" to justify encroachment by the government upon constitutional parental and religious rights of parents, even in the context of divorce ....

The key, is not whether the child experiences stress, but whether the stress experienced is unproductively severe. ${ }^{92}$

Whether this approach is driven by free exercise considerations, a desire to preserve the relative equality of influence between the two parents, or a desire to keep one religious tradition from overpowering the child, the result is quite consistent with the separation-of-powers principle. The "confusion" decried by those courts that prohibit the noncustodian to expose his children to his religion is nothing more than the inevitable result of multiple and separate influences on important matters in a

92574 A2d at 1155 (emphasis omitted). 
child's life. The protection of the possibility of multiple influences is not aimed at the nihilistic end of a negation of values and traditions; rather, it is designed to leave the child free to grow into his own, undominated adult self.

\section{Issues of social welfare policy.}

There are a number of social and economic policies that the government might revise to maximize incentives for adults to create and maintain two-parent families. ${ }^{93}$ In the interests of brevity, I focus only upon one obvious candidate for reform. The limitation of Aid to Families with Dependent Children ("AFDC") to households with an absent parent is one of the great policy disasters of late-twentieth-century America. ${ }^{94}$ By creating incen-

${ }_{93}$ For a general discussion and recommendations, see Elaine Ciulla Kamarck and William A. Galston, A Progressive Family Policy for the 1990s, in Will Marshall and Martin Schram, eds, Mandate for Change 153-178 (Berkeley, 1993); Mary Ann Glendon, The Transformation of Family Law: State, Law \& Family in the United States and Western Europe (Chicago, 1989).

This Article does not address the interesting suggestions that have been advanced with regard to changing the procedure or substance of divorce law for families with minor children. For example, Professor Glendon has advanced the "children first" principle concerning disposition of family property upon divorce. See Transformation of Family Law at 203-07. Elaine Kamarck and William Galston have suggested "braking mechanisms," designed to slow the process and ensure that parents focus on the consequences for their children if the divorce proceeds. Progressive Family Policy at 170-72. See also Lynn D. Wardle, No-fault Divorce and the Divorce Conundrum, 1991 BYU L Rev 79, 133-37; Elizabeth S. Scott, Rational Decision-Making about Marriage and Divorce, 76 Va L Rev 9, 87-91 (1990). These suggestions are driven by a desire to preserve intact, two-parent families when minor children are present, or at least to protect the children's interests if divorce does occur. I am a supporter of the "children first" principle-indeed, I think that a strong presumption in favor of joint physical and legal custody is quite consistent with that principle. I do not believe, however, that the braking mechanism will change the rate of divorce-which is driven by its own emotional and psychological dynamics, and is unlikely to be affected by waiting periods-so much as affect the outcome of divorce for children.

9s To qualify for AFDC, a dependent child must be needy and "deprived of parental support or care by reason of the death [or] continued absence from the home . . . of a parent...." 42 USC $\$ 606$ (a) (1988). This provision has given rise to extensive abuse of welfare families by state welfare bureaucracies, searching for evidence that the absent parent (or his financial support) are not truly absent, and has for many years been criticized from both the right and the left on the ground that it encourages parents to desert their children so that the other parent-custodian and the children will qualify for welfare benefits. See Michael C. Barth, George J. Carcagno, and John L. Palmer, Toward An Effective Income Support System: Problems, Prospects, and Choices 86 (Institute for Research on Poverty, Wisconsin, Madison, 1974); George Gilder, The Coming Welfare Crisis, reprinted in How to Think About Welfare Reform for the 1980's, Hearings Before the Subcommittee on Public Assistance of the Committee on Finance, 96th Cong, 2d Sess 380 (1980) ("AFDC [ ] offers a guaranteed income to any childraising couple in America which is willing to break up ...."); Charles Murray, Losing Ground: American Social 
tives for parents to leave their children, the system offends the basic goals of the separation-of-powers principle. In place of a parent as the source of checks and balances, AFDC substitutes an overburdened bureaucracy with many children to attend to. Whatever shape welfare reform may ultimately take, this policy should be changed.

\section{B. External Restraints-Checks and Balances against the Family}

Up to this point, this Article has focused on separation of powers within families, even those ruptured by divorce. In this Section, I show how the principle might work to enable institutions outside the family to protect children against potentially harmful influences from within their families.

Viewed through the prism of the public/private distinction, the role of mediating institutions acting from outside the family is somewhat more complex than the role of adult family members checking one another. External protection of children will sometimes involve a competing private institution (such as a teacher, clergyperson, or doctor), and at other times the state's institutions. ${ }^{95}$ Furthermore, the extrafamilial institution, whether private or public, will often be backed by state law in its intrusion into the family.

Nevertheless, these cases-most of which involve crucial matters of long-term consequence, such as education or health care-also concern the relation between mediating institutions and individual children. On most matters, the family will suffice to protect children through internal power separation and general standards of child welfare. On matters of life-long significance, however, policy makers should reinforce protection for children by allocating power to institutions outside the family as well as encouraging power separation within it.

\footnotetext{
Policy, 1950-80 154-66 (Basic Books, 1984) (AFDC creates a structure in which fathers have more disposable income if they do not get married.).

95 It may sound odd to speak of the state's own institutions as "intermediaries," but I believe that some function that way for the purposes of this inquiry. Legislatures-the bodies that are perhaps quintessentially "the state"-tend to have power that is general in its ambit and geographically wide in its effect. Some agencies of the state, specialized in their function and noncoercive in their ordinary operations, are in many ways more analogous to private actors than they are to institutions of general and state-wide power. To the extent this is true, public schools and medical facilities, for example, may function as mediating institutions for those within their community to the same extent as private schools and medical facilities. This functional view of the state is quite consistent with that expressed in Dan-Cohen, $61 \mathrm{U}$ Chi L Rev at 1215-16 (cited in note 1).
} 
In education, health care, and protection against the most egregious forms of abuse, our society and legal system have allocated power and responsibility in this dual way. In all of these cases, sources outside the family serve as vital social checks on familial domination and long-term child detriment. This Section of the Article explores the separation of powers between families and external institutions for the protection of children.

\section{Educational choices.}

State and local administrators act to ensure that all children receive an education consistent with the dictates of compulsory education laws. ${ }^{96}$ Under ordinary circumstances, such laws achieve extremely important objectives of power separation. Because they are coupled with parental freedom to choose among schools, ${ }^{97}$ such laws tend to result in the familial choice of significant extrafamilial authority. That is, families choose schools, which in turn choose teachers, and teachers and parents then can check one another.

By dividing power and influence over children among parents and school personnel, compulsory education laws reduce the risk of totalitarian control or abuse of children. Teachers are an unusually important source of information and values, ${ }^{98}$ models of behavior, and safe outlets for concerns that children feel they cannot share with parents. ${ }^{99}$ Parents, of course, can serve sim-

96 See, for example, Mass Ann Laws ch 76, $₹ 1$ (Law Co-op 1991) (requiring children to attend public day school or an alternative school, which the school committee shall approve if it is "satisfied that the instruction in all the studies required by law equals in thoroughness and efficiency, and in the progress made therein, that in the public schools in the same town").

97 Significant constraints exist on school choice for those families unable to afford private schools or communities with the best public schools. Even families so constrained, however, may be able to choose among various communities with different philosophies of education, or to choose among schools within a given system.

98 Of course, teaching values in public school, where children attend under compulsion of law, gives rise to significant constitutional questions. For important recent accounts of the schoolbook wars waged by fundamentalist parents against public schools, see Stephen Bates, Battleground: One Mother's Crusade, The Religious Right, and the Struggle for Control of Our Classrooms (Poseidon, 1993), recounting and analyzing the conflict over textbooks in Mozert v Hawkins County Board of Education, 827 F2d 1058 (6th Cir 1987); Naomi Maya Stolzenberg, "He Drew A Circle That Shut Me Out": Assimilation, Indoctrination, and the Paradox of a Liberal Education, 106 Harv L Rev 581 (1993). The schoolbook wars are undoubtedly about separation of powers over children. The authority to choose what children read and discuss is a major fount of influence to shape their views of the world; thus, these wars are fought among parents, school offcials, and others with intensely held views about what children should and should not read.

99 For an argument that public educators should be held to legal standards that 
ilar functions in relation to other adults, including teachers, in a child's life. The result of multiple adult influences over education-which consumes much of a child's time and which a child can readily appreciate is of great social and personal significance-is the enhanced probability that the child will be exposed to conflicting adult perspectives on serious matters. The child must absorb and intellectually process these conflicts in order to maintain adequate relationships with the important adults in her life. In so learning to manage the differences among teachers and parents, a child reared in a regime in which teacher and parent power are separated is more likely to learn to think for herself and to perceive the ways in which she is a citizen of a larger community, in which conflict and disagreement on a wide variety of subjects are inevitable, than a child raised in a regime of highly concentrated authority. Power separation here thus protects our future as a democratic society as well as the interests of children who will become its adult citizens. ${ }^{100}$

Parents who exercise their power to select their children's teachers by choosing to teach their children at home-that is, parents who choose themselves-put the power-separation principle to the test. Sometimes these choices arise from the parents' religious convictions; in other cases, parents may choose home education out of distrust of the quality of available schools, fear for their child's safety or well-being in those schools, or singleminded devotion to their child's educational attainment.

State responses to the loss of power separation engendered by home education run along a continuum from complete tolerance of parental choices to total prohibition of the at-home option. Either extreme on that continuum represents a polar position on the power separation principle. Total prohibition of the at-home option, if effective, will maximize power separation. ${ }^{101}$

would promote their acting as such outlets, see Joan L. Neisser, School Officials: Parents or Protectors? The Contribution of a Feminist Perspective, 39 Wayne L Rev 1507, 1542-47 (1993) (advocating a "concerned and responsible caretaker" standard).

${ }_{100}$ See generally Amy Gutmann, Democratic Education (Princeton, 1987); William A. Galston, Liberal Purposes: Goods, Virtues, and Diversity in the Liberal State 243 (Cambridge, 1991); Suzanna Sherry, Without Virtue There Can Be No Liberty, 78 Minn L Rev 61, 78-82 (1993) (arguing that the state must ensure that children are educated for democratic citizenship). Dr. Charles L. Glenn, director of the Bureau of Equal Education Opportunity for the Massachusetts Department of Education and a self-described "evangelical," said it well: "As a parent, I want my children to be exposed to strong convictions in school, including those that I do not share-not to be bored into a kind of moral indifference." Curriculum in the Public Schools: Can Compromise Be Reached?, The Christian Century 441 (May 6, 1987).

101 North Carolina once effectively did so, and the courts upheld the constitutionality 
The closer the state comes to complete tolerance of home education, the more it undermines the power separation values of compulsory attendance at some form of school. ${ }^{102}$

Up to a point, the Constitution protects parental choice of schooling for their children, but that point probably falls short of what home schoolers claim. Parents who seek to home school typically advance several constitutional theories to support their claim of exemption from the duty to send their children to an accredited school. The first, and most general, of these theories is that of parental autonomy in decisions concerning the education of their children. This theory forms a part of the modern doctrine of substantive due process, and finds its genesis in a trilogy of Supreme Court decisions from the 1920s. In these three cases-Meyer $v$ Nebraska, ${ }^{103}$ Pierce $v$ Society of Sisters, ${ }^{104}$ and Farrington $v$ Tokushige ${ }^{105}$ - the Supreme Court invalidated state legislative efforts to limit the educational opportunities that parents could provide for their children. ${ }^{106}$

The contemporary view of the Meyer trilogy suggests that it has been reborn as a First Amendment doctrine limiting states' power to contract available knowledge, without necessarily hav-

of the statute. Duro $v$ District Attorney, Second Judicial District of North Carolina, 712 F2d 96, 99 (4th Cir 1983). The home schoolers in North Carolina thereafter successfully lobbied for political change to their benefit. For a description and a general analysis of the judicial losses and political successes of fundamentalist Christian educational options around the country, see Devins, 60 Geo Wash L Rev at 824-39 (cited in note 30).

${ }_{102}$ Some states constrain parents only by periodic testing of the children's academic progress. See, for example, Or Rev Stat $\S 339.035$ (3) (1993). A law review comment lists Oregon as one of nine states whose statutes authorize home education but impose a testing requirement. Comment, The Constitutionality of Home Education Statutes, 55 UMKC L Rev 69, $76 \mathrm{nn} 69-70$ (1986). At the time of that comment, the most common regulatory constraint on home education was a requirement that the home instructor meet specified criteria for certification. Id at 76-79. This was a significant impediment to home schooling because many parents who wanted to educate their children exclusively at home could not meet the certification criteria. According to Devins, 60 Geo Wash $L$ Rev at 819 \& nn 6-7 (cited in note 30), twenty-three states have repealed teacher-certification requirements for home schooling since 1982; only Michigan still retains them.

${ }^{103} 262$ US 390 (1923) (holding that states may not forbid foreign-language instruction of children).

${ }_{104} 268$ US 510, 534-35 (1925) (holding that states may not prohibit private school instruction as an alternative to compulsory education in the public schools).

${ }_{105} 273$ US 284, 298-99 (1927) (holding that the territorial government of Hawaii could not pervasively regulate "foreign language schools," in which students received instruction in Japanese language and culture as a supplement to the instruction in English given in the ordinary schools of the Territory).

${ }^{106}$ All three cases involved statutes enacted in the period of extreme nativism that followed the First World War. Meyer and Farrington precluded state legislation that forbade or severely intruded upon the process of foreign language instruction; Pierce precluded state legislation that required all children to attend public school. 
ing lost its vitality as a more generalized Fourteenth Amendment doctrine ensuring parental control over their children's education. ${ }^{107}$ To the extent the trilogy is viewed as advancing First Amendment values, compulsory-school-attendance requirements would appear legitimate; such requirements tend to expand, rather than contract, the likelihood of increased transmission of knowledge by multiplying the number of influential adults in a child's life. By contrast, a general theory of parental autonomy would tend to suggest that increased constitutional respect for a parental preference for home education over more formal, institutionalized alternatives is appropriate. Runyon $v \mathrm{McCrary},{ }^{108}$ decided in 1976, upheld a federal prohibition of racial exclusion from private schools against a Meyer-based claim, thereby tilting the law against the broad scope of parental autonomy claimed by the home education movement. ${ }^{109}$

The other major theory of parental rights in home education cases arises from the First Amendment guarantee of free exercise of religion. Wisconsin $v$ Yoder ${ }^{110}$ which upheld free exercise

iot Meyer, Pierce, and Farrington were, as originally decided, of a piece with the economic due process cases of the late nineteenth and early twentieth centuries. See, for example, Lochner $v$ New York, 198 US 45 (1905) (invalidating, on due process grounds, a law prescribing maximum hours for those employed as bakers). That is, the Meyer trilogy rested on an expansive concept of common law liberty, a restrictive view of state police power, and an aggressive view of judicial power to enforce the Fourteenth Amendment. The Court's abandonment of that general view in the late 1930s, see West Coast Hotel Co. $v$ Parrish, 300 US 379 (1937), called into question the validity of the Meyer trilogy.

The trilogy's continued vitality was both signalled and temporarily rerationalized in Griswold $v$ Connecticut, 381 US 479, 482 (1965) (invalidating Connecticut statute that prohibited the use of contraceptives even among married couples), in which the Court (per Justice Douglas) cited Meyer and Pierce as cases that implement a First Amendment principle that "the State may not... constrict the spectrum of available knowledge." Subsequent to Griswold, the Supreme Court has appeared to restore the broader conception of the Meyer trilogy as cases that rest upon some version of parental autonomy over children. See Parham $v$ J.R., 442 US 584, 602 (1979). For a discussion of Parham, see text accompanying notes 130-31. See also Runyon $v$ McCrary, 427 US 160, 176-77 (1976) (holding that a prohibition against racially segregated private schools does not violate any right of parental autonomy conferred by the Meyer trilogy).

For a more elaborate discussion of the place of Meyer and Griswold in the historical development of Fourteenth Amendment limitations on the states, see Ira C. Lupu, Untangling the Strands of the Fourteenth Amendment, 77 Mich L Rev 981, 986-1003 (1979). For an articulate critique of the general trend in contemporary constitutional law to intervene in state law decisions concerning the family, see Earl M. Maltz, The State, the Family, and the Constitution: A Case Study in Flawed Bipolar Analysis, 1991 BYU L Rev 489.

108427 US 160.

${ }_{109}$ Professor Woodhouse has given ample reason to be wary of expanding the parental autonomy theory of Meyer and Pierce. Woodhouse, $33 \mathrm{Wm} \&$ Mary I Rev at 995 (cited in note 22) (describing those decisions as extensions of an ideology in which children were viewed as their parents' property).

110406 US 205 (1972). 
claims of several Old Order Amish to remove their children from formal schooling upon completion of the eighth grade, is the most directly relevant decision. ${ }^{111}$ The scope of Yoder, however, is not obvious; certainly its idiosyncratic facts may be read to strictly limit its holding. The Amish sent their children to school through the eighth grade (thus assuring basic literacy), and had for centuries been a self-sufficient community. Moreover, the Amish, unlike many parents who prefer to educate their children at home, pursued a communitarian program of vocational education for their teenagers. Indeed, the communitarian quality of Amish education sweeps it within, rather than without, the separationof-powers principle.

On this view of Yoder, broad prohibition of home education would be consistent with the constitution so long as parents remain free to choose among public or private, secular or religious schools. ${ }^{112}$ Yoder, Meyer, and Pierce all concern affirmative choices to involve the child in an educational community larger than the family itself. These cases should not be read as authority for a parental right to exclude all but themselves from the educational process. When family choices are defined not by affirmation of community but by whom they fence out, as might be said of the all-white academies that Runyon held to be outside the zone of protected associational options, the constitutional force behind parental authority may fade. ${ }^{113}$

111 The Supreme Court's decision in Employment Division $v$ Smith, 494 US 872 (1990), eviscerated the doctrine of free exercise exemptions from laws of general applicability. Smith purported to "preserve" Yoder by treating it as a case of "hybrid" rights, involving free exercise and parental control. Whether or not that distinction can bear the weight it was given, which I doubt, Congress has expressly repudiated the general doctrine of Smith and explicitly reinvigorated that of Yoder in the Religious Freedom Restoration Act of 1993, Pub L No 103-141, 107 Stat 1488 (1993), codified at 42 USCA 2000bb (Supp 1994) ("RFRA").

For discussion of the RFRA, see Eisgruber and Sager, $61 \mathrm{U}$ Chi L Rev at 1306-11 (cited in note 91); Ira C. Lupu, Statutes Revolving in Constitutional Law Orbits, 79 Va L Rev 1, 52-66 (1993); Ira C. Lupu, The Lingering Death of Separationism, 62 Geo Wash L Rev 230, 273-76 (1994); Ira C. Lupu, Employment Division v. Smith and the Decline of Supreme Court-Centrism, 1993 BYU L Rev 259, 270-73; Douglas Laycock, The Religious Freedom Restoration Act, 1993 BYU L Rev 221; Douglas Laycock, Free Exercise and the Religious Freedom Restoration Act, 62 Fordham L Rev 883, 895-97 (1994); Note, Smith and the Religious Freedom Restoration Act: An Iconoclastic Assessment, 78 Va L Rev 1407 (1992).

112 Whether the process and substance of school accreditation in the states might be vulnerable to federal constitutional attack in some instances is a question that this Article does not address. Courts have tended to uphold state regulation of the quality of religious schools. See, for example, Sheridan Road Baptist Church v Department of Educaton, 426 Mich 462, 396 NW2d 373, 382 (1986) (holding that a state may require certification of teachers in parochial school).

${ }^{113}$ Runyon, 427 US at 175-76. See generally William P. Marshall, Discrimination and 
If this analysis of the cases is correct, home education is not a choice protected by the Constitution against state regulation or prohibition. Home education, because it involves the family excluding all those outside of itself, does not earn the imprimatur given by Yoder to communitarian choices protected by the right of association. ${ }^{114}$ Moreover, a right to educate one's children exclusively at home cannot be sustained on the basis of Meyer's First Amendment theory, because there is no reason to believe that prohibiting home education will in any way contract the spectrum of knowledge. A requirement of compulsory school attendance in no way undermines the parents' ability to supplement their children's formal education in whatever ways the parents choose.

If the Constitution thus permits states to encourage, tolerate, or prohibit home schooling, what should states do? Although the power separation principle suggests that prohibition is the most child-oriented course, experience with families who are strongly committed to home schooling suggests this approach may face serious enforcement difficulties. Such families are convinced that home schooling is the best possible course for their children, and will not lightly cede control of their children's education to a state bureaucracy that they mistrust. Indeed, in a number of states, attempts to enforce minimum requirements for teacher training or other matters have run into determined resistance. ${ }^{15}$

the Right of Association, $81 \mathrm{Nw} U \mathrm{~L} \operatorname{Rev} 68$ (1986).

114 Nor is the parental choice of home education protected by the right of familial association found in cases like Moore $v$ City of East Cleveland, 431 US 494 (1977), and Zablocki $v$ Redhail, 434 US 374 (1978). Moore upheld the right of family members to reside in the same household, and Zablocki struck down a state law that prevented a competent adult with child-support obligations from marrying without court approval. Both cases thus involved state restrictions on the process or activity of family formation. The home education cases, by contrast, involve state regulation of parental choices in families already formed. For an example of constitutional validation of such regulation, see Prince $v$ Massachusetts, 321 US 158 (1944) (holding that a state may regulate the distribution of religious pamphlets by a minor at the instruction of her adult guardian under the state's right to regulate child labor). For a more elaborate discussion of Moore and Zablocki, see Lupu, 77 Mich L Rev at 1015-27, 1051-54 (cited in note 107).

115 Devins, 60 Geo Wash L Rev at 824-35 (cited in note 30). In a number of states, education officials and courts have tried the middle ground of tolerating home education under substantive educational standards administered by town officials. See, for example, Care and Protection of Charles, 399 Mass 324, 504 NE2d 592, 599-600 (1987) (holding that states may require home schools to submit proposals of curricula, materials to be used, and qualifications of instructors for approval). I discussed Charles in detail in Ira C. Lupu, Home Education, Religious Liberty, and the Separation of Powers, 67 BU L Rev 971 (1987), where I tentatively introduced the power separation theory that informs this 
Creating martyrs and civil disobedients through batteringram enforcement of compulsory education laws neither advances education nor promotes the policies behind power separation. When parental determination is as strong as it often is in these cases, state officials certainly need new strategies. But concern for the goals of power separation counsels against strategies that take the path of least resistance-essentially abandoning the children to their teacher/parents-and toward some form of engagement. Even without prohibiting home schooling, state officials can work to ensure that children have multiple adult influences, including extrafamilial ones, in their lives.

For example, rather than yield to the temptation to abandon home-schooled children to the minimalist regime of annual progress testing, ${ }^{116}$ state officials responsible for certifying home school arrangements might insist that parents not be the exclusive teachers for their own children. ${ }^{117}$ Officials, of course, may not dictate who the other teachers should be-that is for parents to choose-but they should take care that extrafamilial teachers play an important role. Such teachers might include church representatives, athletic coaches, leaders of scouting or other organized activities, or other parents in the community who are engaged in home schooling. Conditioning home schooling on the significant participation of extrafamilial adults in the educational process furthers power separation values without totally undermining the parents' desire to be the central teachers in their children's lives.

\section{Health care.}

In matters of health care, those entrusted with custodianship of children operate under the more general umbrella of the civil and criminal law of child neglect. That is, unlike the law of compulsory education, which charges custodians with ongoing affirmative obligations to ensure the education of minors, the relevant law concerning physical well-being is far more general and minimalist. The obligation to avoid neglect does not require any particular quantum of health care; rather, it obliges custodians to attend to whatever debilitating conditions the child might suffer. ${ }^{118}$

Article. Jane Cohen and Akhil Amar both encouraged me to proliferate the insight, which I have here tried to do, and I thank them both.

116 See note 102.

117 This may require some alteration in the authority of these officials under state law.

118 See, for example, Fla Stat $\$ 415.503(9)(f)$ (1993) (" $[\mathrm{H}]$ arm to a child's health or 
The source of checks and balances on questions of health care may come from within the family itself. Co-custodians may successfully override their partners on matters of health care, and other interested family members may persuade a custodian to respond to a child's health needs. As in the case of education, however, law and policy add checks and balances from outside the family. In cases in which custodians fail or refuse to pursue adequate health care for their minor wards, state officials and members of the medical professions ${ }^{119}$ may intervene. Neglected children may come to their attention as a result of sudden emergencies, reports from school officials, or other sources. In such instances, the judgment of persons outside the family may be pitted against that of custodians on matters of child health and welfare.

In cases of simple neglect of children with highly debilitating conditions, these issues are easily resolved. If a child's health is in serious jeopardy, and her custodians are without justification in failing or refusing to seek appropriate medical care, state authorities may petition for temporary custody or guardianship of the child. Once the request is granted, these officials may consent to medical treatment for the child. ${ }^{120}$

The more difficult cases of this genre involve one or more complicating characteristics. The first is religion, which is a factor in most of the disputed cases. ${ }^{121}$ When parents opt for heal-

welfare can occur when the parent or other person responsible for the child's welfare ... [f] [ials to supply the child with adequate . . . health care . . . "); Ind Code $\$$ 31-64-3(a)(1) (1978) ("A child is in need of services if . . . [the child's] physical or mental condition is seriously impaired or seriously endangered as a result of the inability, refusal, or neglect of the [child's] parent, guardian, or custodian to supply the child with necessary ... medical care ....").

11 These categories may of course overlap, as in the case of a nurse or doctor working in a public school.

${ }_{120}$ See Matter of Hamilton, 657 SW2d 425, 429 (Tenn App 1983) (authorizing the State Director of Human Services to approve medical treatment on behalf of a child after her father refused to consent to life-saving medical treatment on religious grounds); In re Eric B., 189 Cal App 3d 996, 235 Cal Rptr 22 (1987) (same). See generally Note, Choosing for Children: Adjudicating Medical Care Disputes Between Parents and the State, 58 NYU L Rev 157 (1983).

121 See generally Note, 58 NYU L Rev at 161 \& n 22 (examining a case in which parents refused to consent to a blood transfusion for their child because of their religious beliefs and listing factually similar cases); Barry Nobel, Religious Healing in the Courts: The Liberties and Liabilities of Patients, Parents, and Healers, 16 Puget Sound L Rev 599 (1993) (examining cases that implicated religious parents' rights and responsibilities with respect to health care for their children); Christine A. Clark, Religious Accommodation and Criminal Liability, $17 \mathrm{Fla}$ St U L Rev 559, 560-61 (1990) (describing the large number of states that make statutory accommodations for faith healing by parents); Ann MacLean Massie, The Religion Clauses and Parental Health Care Decisionmaking for 
ing by spiritual faith instead of faith in secular science, they bring the Free Exercise Clause into the picture alongside their parental autonomy rights.

A second complicating factor is the degree of danger to the child presented by the parents' refusal to pursue conventional medical care. This danger is not uniform; as one might expect, the state's power to intervene and substitute its decision about medical care for that of the family is much greater when the child's life is threatened than in cases of less severe illness. ${ }^{122}$ Indeed, even in cases of religious objection to medical treatment, life-threatening illness gives rise to the "compelling interest" the state requires to intervene.

Finally, the timing, in relation to the child's condition, of the state response to a familial refusal to supply medical care has important consequences. When the state intervenes punitively after parental failure to supply secular medical care to a very sick child has led to the child's demise, the standard instrument of intervention is the criminal law. That is, these cases usually involve the tragic combination of parental reliance on spiritual healing, the death of the child, and prosecution of the parents for manslaughter. ${ }^{123}$ In such cases, the community's conscience-as represented by the jury-plays a central role. In contrast, state intervention to provide medical care to a child through temporary shifts in custody typically involves a professional and bureaucratized judgment, not a retrospective and reflective communitarian one. ${ }^{124}$

Children: Suggestions for a New Approach, 21 Hastings Const L Q 725, 747-73 (1994) (arguing that statutory protection for parents' reliance on spiritual healing for their children violates the Religion Clauses of the First Amendment); Note, "Suffer the Little Children... ": Toward a Judicial Recognition of a Duty of Reasonable Care Owed Children by Religious Faith Healers, 16 Hofstra L Rev 165 (1987) (arguing that the compelling state interest in protecting children justifies the prosecution of faith healers); Note, California's Prayer Healing Dilemma, 14 Hastings Const L Q 395 (1987) (criticizing a California statute regulating prayer healing).

${ }_{122}$ See, for example, In re Green, $452 \mathrm{~Pa} \mathrm{373,307} \mathrm{A2d} \mathrm{279,} 280$ (1973) (holding that a 17 year old-and his family-may refuse corrective spinal surgery that would affect his quality of life, but was not a matter of life and death).

${ }^{123}$ For examples of decisions refusing to exempt faith-healing parents from criminal prosecutions after the death of the child, see Walker $v$ Superior Court, 47 Cal 3d 1121, 763 P2d 852 (1989); Hall $v$ State, 493 NE2d 433 (Ind 1986). For examples of decisions reversing criminal convictions in these circumstances on grounds of good-faith reliance on civil statutory exemptions for faith healing, see Commonwealth $v$ Twitchell, 416 Mass 114, 617 NE2d 609 (1993); Hermanson v State, 602 S2d 775 (Fla 1992).

${ }_{124}$ The state may also intervene, albeit in a more oblique form, by permitting a tort action by parents against a faith-healing church after a child in the church's care dies. For example, a Minnesota jury recently awarded compensatory and punitive damages against 
All of these situations may be fruitfully understood through the prism of power separation. Children in need of serious medical attention are at risk. The risk may be one of final and irreparable harm; or it may be lesser yet considerable, as in cases involving children who require cosmetic surgery to repair a significant physical deformity. ${ }^{125}$ Because either parent may be able to block the provision of medical treatment, the intrafamily power separation may be insufficient to protect the interests of children.

The legal system therefore provides a series of extrafamilial checks, in which various actors have authority to override a custodial decision to refrain from medical treatment. In the cases of ex ante intervention, medical authorities and courts may act to temporarily disempower parents or other custodians. In the case of ex post intervention through the criminal law, as when a child dies from a condition treatable with, but not treated by, secular medicine, power is even more divided. These actors include prosecutors, who decide whether and what to charge; medical experts, who must inform others about the medical options that might have been pursued and their likely outcome; judges, who decide what law to apply and how to shape its contours to the case; and jurors, who must make their own conscientious judgments about the extent to which parents may follow their own paths, in good faith, to what turns out to be the child's material detriment. Whether the legal system intervenes before or after the injury to the child, however, it is designed to safeguard the child's interests by allocating power among a number of different parties, none of whom can be sure how the others will behave.

I will explore the separation-of-power principle in three different medical settings-parental control of a minor's access to abortion services, parental commitment of a minor to a mental hospital, and parental decisions concerning a minor's right to die. In each of these three distinctive settings, considerations of policy

the First Church of Christ Scientist in favor of a noncustodial father whose son died after failed attempts at Christian Science healing. See Kevin Duchschere, Judge Cuts Father's Compensatory Sum in Wrongful Death; But Award Upheld against Church, Minn Star Trib B7 (Mar 18, 1994); Margaret Zack, \$5.2 Million Awarded to Dead Boy's Family; Christian Science Practices at Issue in Suit, Minn Star Trib A1 (Aug 19, 1993). But see Brown v Laitner, 432 Mich 861, 435 NW2d 1 (1989) (denying leave to parents to appeal dismissal of their suit against their church, which prescribed faith healing).

${ }_{125}$ Compare In re Seiferth, 309 NY 80, 127 NE2d 820 (1955) (declining to order, over parental objection, cosmetic surgery for a fourteen-year-old boy with massive harelip and cleft palate), with In re Sampson, 29 NY2d 900, 278 NE2d 918 (1972) (ordering, over religious objection of parents, a blood transfusion that was necessary for surgery for a boy with "elephant man" disease). 
and constitutionality mutually reinforce the power separation approach.

Federal constitutional law is quite consistent with the model of separated powers over children when serious questions of health care, involving long-term physical and psychological consequences, are involved. Abortion cases provide the starkest example. Since the question of minors' rights to seek abortions on their own arose in the wake of Roe $v$ Wade, ${ }^{126}$ the Supreme Court has interpreted the Constitution to limit state power to grant parents an absolute veto of a minor daughter's abortion. Beginning with the Court's invalidation of a parental consent provision in the Missouri statute considered in Planned Parenthood of Central Missouri $v$ Danforth ${ }^{127}$ the cases have almost uniformly held that requirements of parental consent be subject to a judicial bypass, pursuant to which a minor is free to present to state court judges questions of her decision-making competence and best interests. ${ }^{128}$

The Supreme Court's decisions about minors' abortions are unmistakably grounded in separation of powers. These decisions recognize that parental power over a daughter's abortion decision presents a substantial risk of domination-that is, of a decision that reflects the parents' values and interests, and takes insufficient account of those of the young woman whose life will be irretrievably altered no matter which way she chooses to proceed. Rather than recognizing the pure autonomy of the minor, however, the decisions reallocate power over her. By requiring the option of a judicial bypass of parental authority in those laws that seek to involve parents in an abortion decision, the Supreme

126410 US 113 (1973).

122428 US 52 (1976).

${ }_{123}$ See Bellotti v Baird, 443 US 622, 642-44 (1979); Planned Parenthood Association of Kansas City v Ashcroft, 462 US 476, 490-93 (1983); Hodgson v Minnesota, 497 US 417, 450-54 (1990); Ohio v Akron Center for Reproductive Health, 497 US 502, 510-17 (1990); Planned Parenthood of Southeastern Pennsylvania v Casey, 112 S Ct 2791, 2832-33 (1992). But compare H.L. $v$ Matheson, 450 US 398, 407-10 (1981) (upholding a parental notice provision, as opposed to a parental consent provision, as applied to an immature and dependent minor, without a judicial bypass provision). Casey manifests ambivalence about a state's authority to allocate moral power over an adult's abortion decision to anyone outside herself. The result in Casey included invalidation of a spousal notice provision in the Pennsylvania law, but all but two Justices voted to uphold informed consent provisions and a twenty-four-hour waiting period which, taken together, suggested doubts concerning the trustworthiness of women to make autonomous moral decisions. $112 \mathrm{~S} \mathrm{Ct}$ at 2826-32, 2822-26. For a powerful critique of this aspect of Casey, see Jane Maslow Cohen, A Jurisprudence of Doubt: Deliberative Autonomy and Abortion, 3 Colum J Gender \& L 175 (1992). 
Court has recognized the risk of parental domination and crafted a process that provides an alternative source of authority to check parental self-interest. ${ }^{129}$

In a different context, the Supreme Court's decision in Parham $v$ J.R. reinforces the strategy found in the minors' abortion decisions. ${ }^{130}$ Parham involved a challenge to Georgia's procedures for "voluntary" commitment of a child to a state mental hospital. The existing state procedures permitted a parent to commit a child for a five-day observation period; if, after examination during that period, mental health authorities found sufficient evidence that 1) the child suffered from mental illness and 2) the child was suitable for treatment, the child would be committed for an indefinite period. During commitment, either the parent or the hospital authorities could terminate the commitment. The Supreme Court upheld this scheme against a procedural due process claim. Although the Court concluded that the due process clause required a neutral factfinder to review the parents' decision to commit the child, that review required neither an adversarial hearing nor a legally or judicially trained trier of fact. ${ }^{131}$

In rejecting the model of procedural due process, with its premises of autonomy of the liberty holder and an adversarial process, in favor of the Georgia scheme, the Supreme Court legitimated a model of power separation instead of children's rights. Commitment to a mental hospital entails a very serious loss of liberty, privacy, dignity, and control over one's life. Such a commitment is likely to have profound repercussions upon one's future, regardless of when the commitment ends. At least in design, the Georgia scheme respected the gravity of the stakes by requiring joint consent among familial and specialized, extrafamilial personnel. ${ }^{132}$ In addition, it incorporated a presumption in favor of constitutional liberties. Under the scheme, two independent actors-the parents and the mental health au-

${ }^{29}$ The bypass judge may refuse the abortion request, just as a second parent may refuse to override the first. The crucial factor relative to separation of powers is the alternative perspective that the bypass judge may provide, free of the pressure and embarrassment likely to be experienced within the family. Of course, not everyone thinks that a power separation solution is sufficient to protect the pregnant minor. See Note, Where Privacy Fails: Equal Protection and the Abortion Rights of Minors, 68 NYU L Rev 597, 636-37 (1993).

130442 US 584 (1979). For a general discussion and critique of Parham, see Robert A.

Burt, The Constitution of the Family, 1979 S Ct Rev 329.

${ }^{131} 442$ US at 606-08, 613-17.

${ }^{132}$ Id at 604 . 
thorities-had to concur before a minor's liberty could be restricted. In contrast, either actor could independently protect the minor's liberty by refusing commitment or deciding to end it.

The similarity between Parham and the minors' abortion problem is striking, and can be fruitfully understood in power separation terms. In both settings, the relevant substantive law contains a libertarian inclination. In the commitment context, that inclination is toward physical liberty; in the abortion setting, the substantive constitutional preference favors the pregnant female's choice, rather than fetal life. In both situations, that substantive preference is reflected in structural devices designed to separate power over the minor and increase the likelihood of the substantively preferred choice. Accordingly, either familial authorities or the bypassing judge may authorize the termination of pregnancy; these authorities must concur to deny the minor the right to an abortion. Similarly, either parents or authorized mental health professionals may preserve or recreate a minor's liberty; these authorities must concur to restrict that liberty.

The results in the minors' abortion and commitment contexts also dovetail with those in cases where adults assert a child's right to die. ${ }^{133}$ Here, too, children's interests are protected by hinging a substantive presumption to the separation-of-powers model. These cases are closely related to those involving an adult's right to die, ${ }^{134}$ with one crucial difference. Because most adults at one time had full decision-making capacity for themselves, one way for family members to become substitute decision makers is through authorization from the patient in a durable power of attorney for health care decisions. Cases involving

${ }^{133}$ My analysis in what follows is limited to those cases in which extraordinary treatment is necessary to prolong a child's life. I do not address the set of cases that concerns the right of parents, acting in concert with health professionals, to withhold ordinary treatment necessary to preserve the life of newborns (or others) afflicted with serious disabling or life-limiting conditions, such as spina bifida or Down's syndrome. See generally Martha A. Field, Killing "the Handicapped"-Before and After Birth, 16 Harv Women's L J 79 (1993). Suffice it to say that in such cases the law tends to separate powers over children still further; that is, it is ordinarily not left to the judgment of the parents and family physician alone whether to treat such children for conditions which, if left untreated by ordinary medicine, are likely to cause their demise. For an example of a statute that directly addresses the problem, see La Children's Code Ann § 1554-55 (West 1994) (limiting situations in which a child may be denied medical care to cases in which the child is in a coma, the child is suffering from a terminal and irreversible condition, or the risks of medical care outweigh its benefits).

${ }^{134}$ The leading federal constitutional case is, of course, Cruzan v Director, Missouri Department of Health, 497 US 261 (1990) (upholding a state law requirement forbidding the termination of artificial nutrition and hydration procedures without "clear and convincing evidence" that the comatose patient would have so chosen). 
adults, in other words, are frequently about ways of reinforcing patient autonomy in treatment decisions. In contrast, children are never legally recognized as having full capacity for making life-and-death treatment choices. As a result, the law presumptively recognizes the substitute judgment of a parental authority-rather than patient autonomy-concerning medical treatment choices.

Like Parham and the minors' abortion cases, the decisions involving children's "right to die" reveal a substantive preference. Indeed, these decisions have created a presumption in favor of the child's life, and therefore require the concurrence of familial and medical authority to terminate extraordinary life-extending measures. Thus, the parents enjoy a veto over a professional decision to terminate such measures.

In the Matter of Baby $K$ provides a good illustration of this "two-to-die, one-to-live" principle. ${ }^{135}$ Baby $\mathrm{K}$ was born with anencephaly, a condition in which "the brain stem is present but the cerebral cortex is rudimentary or absent." ${ }^{136}$ At the time of the decision, Baby $\mathrm{K}$ was permanently unconscious and could not hear, see, or feel pain. From the time of her birth, she had been breathing with the aid of a mechanical ventilator.

Baby K's mother rejected medical and ethical advice to terminate the ventilator treatment. The hospital in which Baby $K$ was being treated transferred the baby to a nursing home during a period in which the baby was able to survive without the aid of mechanical respiration. The hospital, nursing home, and mother agreed that Baby $\mathrm{K}$ would be transferred back to the hospital whenever she again needed ventilator treatment. The hospital, the baby's father (who had not been involved in the baby's care), and a guardian ad litem appointed to represent Baby $\mathrm{K}$ all petitioned for a declaratory judgment that they be free to deny ventilator treatment to the child, without the mother's consent, without being held to violate a variety of federal and state laws. The district court held that Baby K's mother had common law and constitutional rights to refuse to terminate the child's treatment. ${ }^{137}$ Unless the state could show that such refusal consti-

135832 F Supp 1022 (E D Va 1993), aff'd, 16 F3d 590 (4th Cir 1994).

136 Baby K, 832 F Supp at 1025.

${ }^{137}$ Id at 1030-31. The district court cited the Virginia Constitution as well as the Due Process Clause and the Free Exercise Clause of the U.S. Constitution as the sources of protection for the mother's pro-life view, grounded in her religion, of her child's fate. The district court also refused to render a declaratory judgment that the hospital could refuse to treat Baby $\mathrm{K}$ without violating a collection of federal statutes that arguably imposed a 
tuted abuse or neglect of the child, the other parties could not overrule the mother's decision. ${ }^{138}$

Cases like Baby $K$ emphatically separate power over children. These cases grant legal power to parents to insist on continued treatment, regardless of medical recommendations to the contrary. In turn, medical personnel have substantial de facto power to continue treatment when parents want them to stop; given the technical nature of extraordinary treatment, the cooperation of medical personnel will almost always be needed to terminate the procedures.

Of course, either side, parental or medical, can shop for a new partner if death is the objective. Medical personnel who believe that continued treatment constitutes child abuse can petition to have the parent(s) removed as custodian(s), though it will rarely be easy to persuade a judge that the parents' passionate fight for a child's survival constitutes abuse. From the other direction, parents who wish to terminate treatment over the objections of medical personnel can shop for new medical care. If, however, transferring or removing the child from existing treatment will itself be fatal, the treating medical personnel will have substantial leverage and opportunity to resist the move. Thus, power separation in these circumstances, while no guarantee of a particular outcome, protects the underlying value of preserving life. ${ }^{139}$

duty to treat, at least in a case in which a parent insisted upon treatment. Id at 1026-30. The Fourth Circuit affirmed on the question of a hospital's duty to treat under the Emergency Medical Treatment and Active Labor Act, 42 USC § 1395dd (1988), and did not reach the other questions. Baby $K, 16$ F3d 590.

${ }^{139}$ Baby K, $832 \mathrm{~F}$ Supp at 1031 ("In this case, where the choice essentially devolves to a subjective determination as to the quality of Baby K's life, it cannot be said that the continuation of Baby K's life is so unreasonably harmful as to constitute child abuse or neglect."). Presumably, the outcome would have been different if Baby $\mathrm{K}$ were in physical pain and if ventilator treatment prolonged that pain in circumstances in which there was no hope for improvement.

In support of its conclusion, moreover, the district court cited In re Doe, Civ No D93064, mem op at 18 (Super Ct Fulton Co, Ga, Oct 17, 1991), aff'd, 262 Ga 389, 418 SE2d 3 (1992), which addressed the possibility of two parents, both of whom had been closely involved in the child's life and treatment, disagreeing over the termination of life-prolonging treatment. Baby $K, 832 \mathrm{~F}$ Supp at 1030. The district court in Doe also expressed an explicit presumption favoring life, under which either parent can block life-ending medical judgments.

${ }_{139}$ I thus disagree with Professor Rhoden when she argues for a clear rule that family, rather than physicians, should have the controlling word on life-and-death medical decisions. See Nancy K. Rhoden, Litigating Life and Death, 102 Harv L Rev 375, 437-445 (1988). Among other things, family members have too many conflicts of interest built into their circumstances. The suffering that is ended with the death of a terminally ill patient is not the patient's alone. 
The decision of a Michigan Court of Appeals in In re Rose$b_{u s h}{ }^{140}$ is the "right to die" counterpart to Baby $K$. The Rosebush litigation involved Joelle, a ten-year-old girl who had been devastatingly injured in an automobile accident; her spinal cord had been severed just below the neck, most of her cerebral functions had been destroyed, and she was in a persistent vegetative state. Although she was not "brain dead" within the meaning of Michigan law, she would never regain consciousness and never be able to breathe without artificial support.

Joelle's parents, physicians, priest, and lawyer all participated and concurred in the family decision to withdraw Joelle's life support. Before the decision could be implemented, however, staff at the facility where Joelle was being kept alive contacted the district attorney, who successfully obtained a temporary injunction against the withdrawal decision. After a week-long trial, the court dissolved the injunction and authorized Joelle's family and its supporting cast of professionals to remove Joelle from the ventilator. She died shortly thereafter.

Despite the factual mootness of the case, the appellate court affirmed the trial court's order authorizing the removal of the ventilator. The court based its opinion on a "best interests of the child" standard rather than a standard of substituted judgment or some more stringent norm, but that is not the most important aspect of the decision. ${ }^{141}$ Rather, the centerpiece of the opinion is its conception of the role of parents, physicians, and courts. The court rejected the notion, advanced by the district attorney, that treatment-ending decisions can only be made with judicial permission. Instead, the court described its role as limited to breaking an impasse, if one existed, among the more directly interested parties. ${ }^{142}$

Whether or not this decision was motivated by the court's own self-interested desire to avoid life-and-death decisions when possible, this judicial posture is in perfect harmony with the separation-of-powers model. As in Baby $K$, the court assumed that either the family or the attending medical professionals can opt for life. In those cases, however, in which the child requires

140195 Mich App 675, 491 NW2d 633 (1992).

141 Id at $639 \& \mathrm{n} 7$. Because the case involved a child, the issue of "substituted judgment" - that is, what would the patient do if she were conscious and in possession of all the facts-quite appropriately does not arise. Rather, the matter explicitly requires the paternalistic judgment of adults about what would be best for the child and implicitly triggers the self-regarding judgment concerning what is best for themselves.

${ }_{142}$ Id at 639. 
extraordinary treatment to survive, and both the familial and extrafamilial authorities agree not to provide that treatment, they need not obtain judicial permission to pursue their consensual course.

Rosebush raises an important question for the separation-ofpowers principle: to which actors outside the family should the law grant authority over children? The members of the professional staff who called in the district attorney in Rosebush thought that they qualified. The district attorney thought that the state's judges should be indispensable cosignatories to any treatment-ending decision. The Rosebush court held that the judgment of two physicians, not directly involved in the case, was necessary, and that the participation of a hospital ethics committee was helpful but not indispensable. ${ }^{143}$

The question underlying this dispute is the relationship between power over children and distance from them. The model quite rightly rejected by the Michigan court would have given authority to those who had the least human contact with the child and her family-an ethics committee and a reviewing judge. These distant parties are likely to appraise what is "best" for an irreversibly injured child on the basis of a paper record alone. In contrast, family physicians, and the independent physicians one step removed, are far more likely to have spent time with both the parents and the child. The set of relations preferred by the Michigan court is thus precisely that contemplated by the model of power separation. The model does not insist on multiple authorities for their own sake, and it surely does not contemplate that strangers to the child should war over her interests. Rather, the model expresses the hope that different adult parties-each with her own angle of vision and unique interests, but all with a familiarity with the child and a concern for her well-being-will address the child's situation. When life and death are at stake, insisting upon extrafamilial parties with specialized knowledge is eminently appropriate; requiring that such parties include some to whom the child is a metaphor rather than a person does not serve power separation values, and the Rosebush court rightly declined to do so. 
3. Prevention of and response to child abuse.

One might expect that power separation, including a robust version of checks and balances, would be an integral part of the legal system's response to child abuse. The system has not, however, made full use of power separation as a means of detecting and preventing child abuse. It is unclear whether this is so for reasons of preservation of patriarchy, scarcity of resources, or respect for family privacy, which is more directly implicated in the abuse context than in the more episodic and specialized contexts of health and education.

The larger story of the legal system's response to child abuse is far more tangled than can be told here. ${ }^{144}$ Focusing on the close relationship between power and responsibility in this context, however, reveals that internal separation of powers can be no more than a partial solution to this problem.

Parents and legal custodians ordinarily have an obligation to support and protect children as well as the authority to make decisions on their behalf. In matters of child abuse, however, responsibility to stop or prevent abuse is closely linked to the power to cause it. Because of parents' proximity to the child and the likelihood that the child trusts them, parents are in the best position to cause abuse. At the same time, these qualities of the parent-child relationship-proximity, privacy, and trust-also place custodial parents in the best position to identify and deter abuse.

When one parent-custodian abuses a child and the other knows about it, both the incentives and disincentives for mutual monitoring of adult (mis)treatment of children are at their peak. The danger to the child is greatest, but the sense of fear or discomfort at confronting the abuser may be greater still, and the sense of fear or betrayal caused by reporting the abuser to authorities equally large. Moreover, the "innocent" parent-

144 The literature on the subject is vast. See, for example, Elizabeth Pleck, Domestic Tyranny: The Making of Social Policy Against Family Violence from Colonial Times to the Present (Oxford, 1987); Linda Gordon, Heroes of Their own Lives: The Politics and History of Family Violence (Viking, 1988); C. Henry Kempe and Ray E. Helfer, Helping the Battered Child and His Family (Lippincott, 1972); Douglas J. Besharov, "Doing Something" About Child Abuse: The Need to Narrow the Grounds for State Intervention, 8 Harv J L \& Pub Policy 539 (1985); Comment, Lawyering for the Abused Child: 'You Can't Go Home Again," 29 UCLA L Rev 1216 (1982). The legal system's response is complicated by the extreme difficulty of the problems of proof presented by charges that adults have sexually abused very young children. See, for example, Maryland v Craig, 497 US 836 (1990) (holding that courts may dispense with face-to-face confrontation between a child witness and an adult defendant if other Confrontation Clause requirements are satisfied). 
custodian's own need to maintain a relationship with the abuser may also discourage confronting the problem. Here, more perhaps than in any other context, power separation within the family is vital but obviously insufficient to protect the child. ${ }^{145}$

The dynamics of internal monitoring suggest that it is unlikely to be fully effective. The role that noncustodians should play in monitoring and deterring child abuse, however, presents different questions of the relationship among parties in a position to monitor abuse. One particularly noteworthy development is the rise and spread of reporting requirements that the law may impose on various professionals who come into contact with children. ${ }^{146}$ Such requirements are consistent with a power separation strategy; they impose upon adults the task of monitoring others, so as to protect the interests of their mutual wards.

But the tension these laws create among the various adults charged with the protection of children reveals a central paradox in the power separation model. The monitoring process may generate mistrust and reduce the flow of information among adults. In the context of reporting abuse, this mistrust may be pervasive and debilitating. Abusers are unlikely to make voluntary and full disclosure; pressing questions aimed at ferreting out abuse are likely to chase them away. Although power separation concerns support reporting laws, these laws also remind us that the most elaborate schemes of extrafamilial policing may still be insufficient to protect children against a wide array of risks.

Moreover, the police may need policing as well. This is borne out, I believe, by the poor performance record of public agencies assigned to investigate and report child abuse. Report after report of understaffing, bad judgment, and children harmed despite notice to public authorities have numbed many Americans to this problem. ${ }^{147}$ Moreover, agencies may be over- as well as underintrusive. While the latter is obviously worse for children,

${ }^{245}$ See, for example, In re Michael C., 557 A2d 1219, 1220 (RI 1989) (suggesting that a mother had failed to protect her son against sexual abuse by his father because she was "perhaps torn between the love for the child and loyalty to her husband").

${ }_{146}$ Professor Wadlington reports that "[e]very state now has some form of child abuse reporting statute. Typically they mandate reporting by certain persons likely to have personal or professional contact with children who have been injured through abuse. Teachers and health care professionals are examples." Walter Wadlington, Domestic Relations 544 (Foundation, successor ed 1984).

147 For a running account of one major city's struggle with this problem, see Editorial, Dead Children and Civic Duty, NY Times A16 (Jan 30, 1989); Richard Levine, Koch Argues City Can't Totally End Fatal Child Abuse, NY Times A1 (Dec 31, 1988); James LeMoyne, Inquiry Faults City Agency in Child-Abuse Deaths, NY Times B3 (Apr 24, 1984). 
even the former may cause unnecessary family strains and waste public resources. ${ }^{148}$ Power separation, and the mutuality of monitoring it requires, has not been incorporated into the agency context very effectively. For while agencies may monitor custodians, families have little ability or incentive to police the behavior of agencies.

In its most prominent opportunity to deploy the Constitution in service of child protection goals, the Supreme Court performed badly. In DeShaney $v$ Winnebago County Dept. of Social Services, the Court held that the federal Constitution imposed no duty of care upon child protection agencies to remove allegedly abused children from harm's way. ${ }^{149}$ This decision reinforced the lack of accountability in the system. ${ }^{150}$ State law may impose tort liability upon its own agents for such omissions, but there are political and economic pressures not to do so when the state itself is responsible for chronic understaffing of child welfare agencies. ${ }^{151}$ If the state and its agents were liable under federal law for acts and omissions that contributed to the serious abuse of children, the state might well invest additional resources in monitoring misbehavior by custodians.

The DeShaney problem serves as a reminder of the limits of mediating institutions. Although one hopes that such institutions-the family, the neighborhood, the church, the health clinic-will operate to limit the harm that destructive adults may do, these systems often fail. Because the dangers are so great, public power should be available to match the private hazard and the risk of private default. And without public accountability of the

148 The reporting statutes usually insulate those who make reports in good faith from liability for erroneous reporting. See Wadlington, Domestic Relations at 544 (cited in note 146). Failure to report, on the other hand, may give rise to civil sanction, id at 545, or tort liability, see Landeros $v$ Flood, $17 \mathrm{Cal} 3 \mathrm{~d}$ 399, 551 P2d 389, 397 (1976) (upholding a cause of action against a doctor and hospital for failing to report a suspected case of child abuse). This combination creates incentives to overreport, which may or may not be counterbalanced by other incentives to underreport.

149489 US 189, 194-97 (1989).

150 DeShaney has been widely and powerfully criticized. See Akhil Reed Amar and Daniel Widawsky, Child Abuse as Slavery: A Thirteenth Amendment Response to DeShaney, 105 Harv L Rev 1359 (1992); Jack M. Beermann, Administrative Failure and Local Democracy: The Politics of DeShaney, 1990 Duke L J 1078; Steven J. Heyman, The First Duty of Government: Protection, Liberty, and the Fourteenth Amendment, 41 Duke L J 507 (1991); David A. Strauss, Due Process, Government Inaction, and Private Wrongs, 1989 S Ct Rev 53; Aviam Soifer, Moral Ambition, Formalism, and the "Free World" of DeShaney, 57 Geo Wash L Rev 1513 (1989).

${ }_{151}$ For cases concerning state law liability of child welfare workers, see Mark Ellmann, Paul M. Kurtz, and Katharine T. Bartlett, Family Law 1163-64 (Michie, 2d ed 1991). 
sort DeShaney rejects, the likelihood of public power being sufficient to the task is alarmingly small.

\section{CONCLUSION}

This Article has suggested an insight on which the family law literature has not yet focused in a sustained way. Those who care for children can and should be made to grapple with others who care for the same children. This system would not be designed to comfort the grapplers; on the contrary, it might utterly discomfit them, on the theory that forcing them to confront one another over questions of child welfare, small and large, will produce greater accountability and better decisions for children. Power separation, so maintained, would serve the freedom and well-being of those over whom the struggling occurs.

The power separation model proposed here is not designed to sweep away all competing ideas in the complex web of family law. Indeed, I would not wish the model to have that sort of preemptive effect. As all family lawyers know, many variables will quite appropriately commend themselves to the decision maker's attention; overattention to any at the expense of others is likely to harm the children whom the system purports to serve.

Rather than trying to displace all relevant considerations with a unitary focus on power separation, my goal is more modest. I would settle for this: the next time a judge or lawyer thinks about a child's best interests, I hope that she remembers how deeply fallible and imperfect the very best parents, educators, and child care professionals are. I hope she appreciates that the role of mediating institutions in the lives of children is not simply to shield them from the overweening power of the impersonal state, but includes as well the need to protect children from those who wield power within those very institutions. To put it simply, I hope that she concurs in my judgment that children thrive best, and are at least risk, when power over them is separated. 
